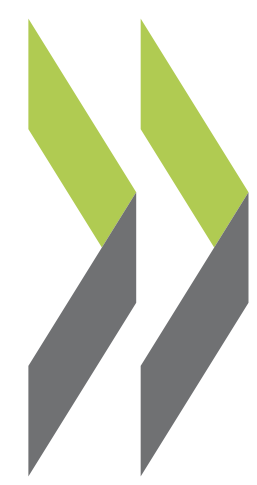

OECD Economics Department Working Papers No. 1611

Assessing the efficiency of environmental policy design and evaluation: Results from a 2018 crosscountry survey

\section{Clara Berestycki,}

\section{Antoine Dechezleprêtre}




\section{ECONOMICS DEPARTMENT}

Cancels \& replaces the same document of 29 June 2020

\section{Assessing the efficiency of environmental policy design and evaluation: Results from a 2018 cross-country survey}

\section{Economics Department Working Papers No. 1611}

By Clara Berestycki and Antoine Dechezleprêtre

OECD Working Papers should not be reported as representing the official views of the OECD or of its member countries. The opinions expressed and arguments employed are those of the author(s).

Authorised for publication by Alain de Serres, Deputy Director Policy Studies Branch, Economics Department.

All Economics Department Working Papers are available at www.oecd.org/eco/workingpapers. 
OECD Working Papers should not be reported as representing the official views of the OECD or of its member countries. The opinions expressed and arguments employed are those of the author(s).

Working Papers describe preliminary results or research in progress by the author(s) and are published to stimulate discussion on a broad range of issues on which the OECD works.

Comments on Working Papers are welcomed, and may be sent to OECD Economics Department, 2 rue André Pascal, 75775 Paris Cedex 16, France, or by e-mail to eco.contact@oecd.org.

All Economics Department Working Papers are available at www.oecd.org/eco/workingpapers.

This document and any map included herein are without prejudice to the status of or sovereignty over any territory, to the delimitation of international frontiers and boundaries and to the name of any territory, city or area.

The statistical data for Israel are supplied by and under the responsibility of the relevant Israeli authorities. The use of such data by the OECD is without prejudice to the status of the Golan Heights, East Jerusalem and Israeli settlements in the West Bank under the terms of international law.

\section{(C) OECD (2020)}

You can copy, download or print OECD content for your own use, and you can include excerpts from OECD publications, databases and multimedia products in your own documents, presentations, blogs, websites and teaching materials, provided that suitable acknowledgment of OECD as source and copyright owner is given. All requests for commercial use and translation rights should be submitted to rights@oecd.org. 


\begin{abstract}
RESUME
Assessing the efficiency of environmental policy design and evaluation: Results from a 2018 crosscountry survey

Ambitious environmental policies are necessary to enable the transition to a greener economy. However, these policies could impose economic burdens on firms through different channels. They may increase barriers to entry and distort competition. They may also impose transaction and administrative costs related to permitting and licensing. If stringent environmental policies can be designed in a way that minimises such economic burdens, they can facilitate the achievement of economic and environmental goals and a cleaner growth model. This paper reports evidence from the 2018 wave of the indicator of the Design and Evaluation of Environmental Policies (DEEP). Across OECD countries, the average DEEP indicator for 2018 has decreased by $18 \%$ compared to 2013 . Over $80 \%$ of surveyed countries saw an improvement of DEEP between the two waves. This was driven mostly by a decline in the distortions to competition and by improved evaluation of environmental policies. Some of these improvements come from a reduction in regulatory burdens across all sectors of the economy but others come from a simplification of permitting procedures and improvements of regulatory assessments that are specific to environmental policies. There is little correlation between DEEP and the OECD's Environmental Policy Stringency indicator, suggesting that stringent environmental policies need not be associated with more burdens on the economy.
\end{abstract}

JEL classification codes: Q58; L50; L59.

Keywords: Environmental policies, environmental regulation, competition, barriers to entry, administrative burdens, public policy evaluation

$* * * * * * * * * * * * * * * * * * * * * * * * * *$

Évaluer l'efficacité de l'élaboration et de l'évaluation des politiques environnementales : Résultats d'une enquête internationale conduite en 2018

Des politiques environnementales ambitieuses sont nécessaires pour permettre la transition vers une économie plus verte. Cependant, ces politiques peuvent imposer des charges économiques aux entreprises de différentes manières. Elles peuvent accroître les barrières à l'entrée et fausser la concurrence. Elles peuvent également imposer des coûts de transaction et administratifs liés à l'obtention de permis et de licences. Si les politiques environnementales ambitieuses peuvent être conçues de manière à minimiser ces charges économiques, elles peuvent faciliter la réalisation des objectifs économiques et environnementaux et un modèle de croissance plus propre. Cet article présente les résultats issus de la version 2018 de l'indicateur de l'élaboration et de l'évaluation des politiques environnementales (DEEP). Dans les pays de l'OCDE, l'indicateur DEEP moyen pour 2018 a diminué de $18 \%$ par rapport à 2013. Plus de $80 \%$ des pays interrogés ont connu une amélioration du DEEP entre les deux vagues. Cette évolution s'explique principalement par une baisse des distorsions à la concurrence et par une meilleure évaluation des politiques environnementales. Certaines de ces améliorations proviennent d'une réduction des charges administratives dans tous les secteurs de l'économie, mais d'autres proviennent d'une simplification des procédures d'autorisation et des améliorations de l'évaluation des politiques publiques qui sont propres au domaine de l'environnement. Il existe peu de corrélation entre le DEEP et l'indicateur de sévérité des politiques environnementales (EPS) de l'OCDE, ce qui donne à penser que des politiques environnementales plus strictes ne s'accompagnent pas nécessairement de charges plus lourdes pour l'économie.

Classification JEL : Q58 ; L50 ; L59.

Mots-clés : Politiques environnementales, réglementation environnementale, concurrence, barrières à l'entrée, charges administratives, évaluation de politiques publiques 


\section{Table of Contents}

Assessing the efficiency of environmental policy design and evaluation: Results from a 2018 cross-country survey

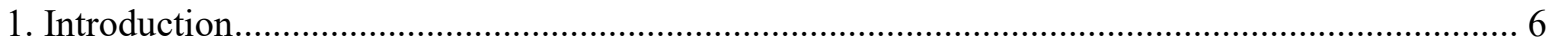

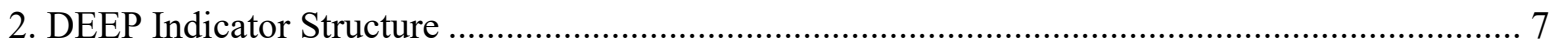

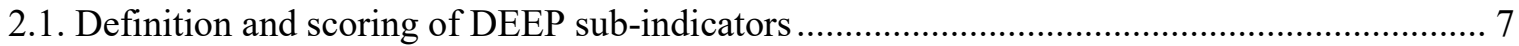

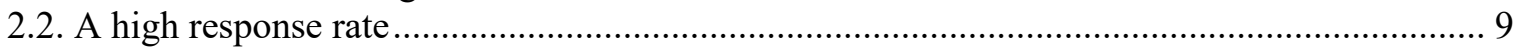

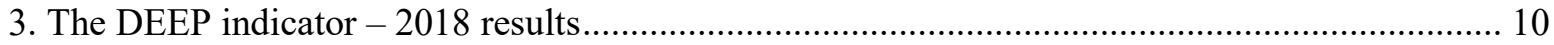

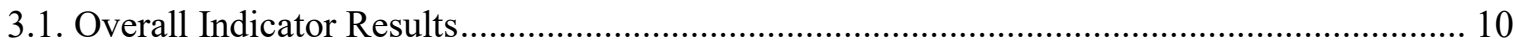

3.2. Correlation of DEEP 2018 with other environmental and regulatory indicators .................... 11

3.3. A look inside in the DEEP: Comparing environmental permitting procedures ....................... 13

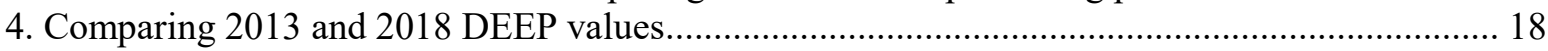

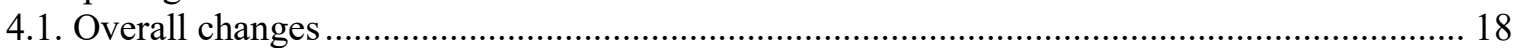

4.2. Between 2013 and 2018, environmental policy became more compatible with competition. 20

4.3. Environmental Policy Evaluation is more systematic and transparent.................................. 21

4.4. The evolution of DEEP strongly correlates with that of environmental and regulatory

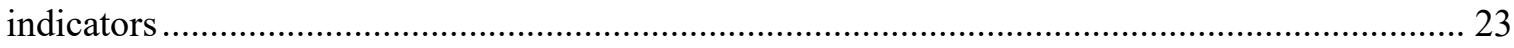

4.5. Correlation between the evolution of DEEP and the evolution of PMR ................................ 24

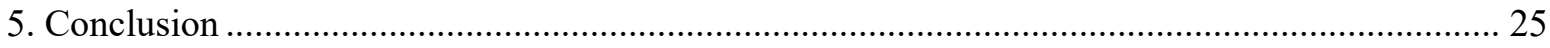

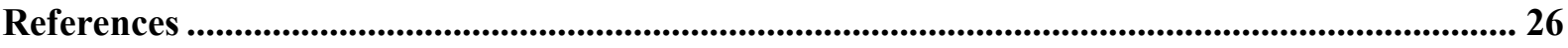

Annex A. Correlation Tables..................................................................................................................... 27

Annex B. Correlation between permitting costs and environmental policy stringency............... 29

Annex C. Summary statistics for Permitting Times and Costs ..................................................... 30

Annex D. Breakdown of DEEP per country ................................................................................................... 31

Annex E. Scoring and aggregation procedures......................................................................................... 32

Annex F. Country Response Rates to EEP questionnaires.................................................................... 37

\section{Tables}

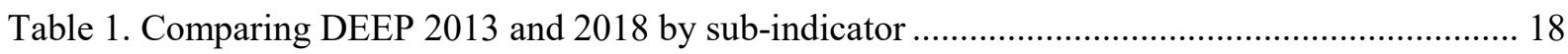

Table A.1. Correlation between DEEP and environmental indicators ................................................ 27

Table A.2. Correlation between DEEP and Fraser Institute Indicators on Regulation ........................ 27

Table A.3. Correlation between DEEP and Ease of Doing Business (World Bank)............................ 27

Table A.4. Correlation between DEEP and World Economic Forum Competitiveness Indicators ..... 28

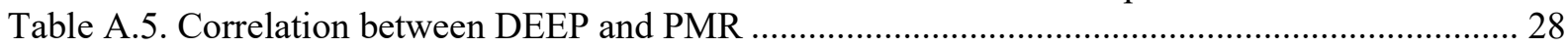

Table A C.1. Summary Statistics for Permitting Times and Costs .................................................... 30

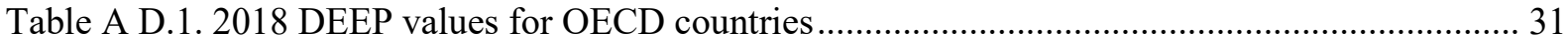

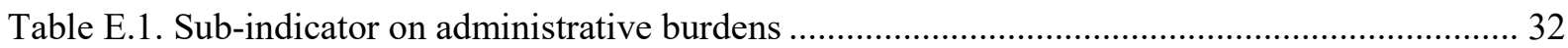

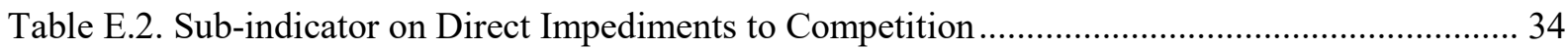

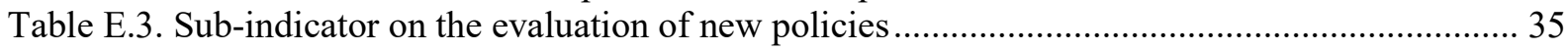


Table E.4. Sub-indicator on the evaluation of existing policy 36

\section{Figures}

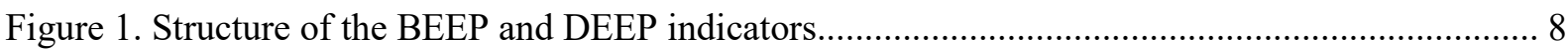

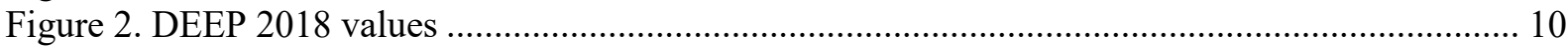

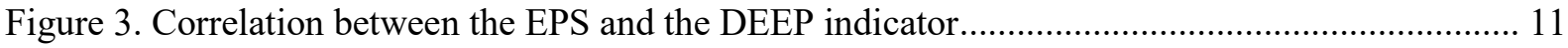

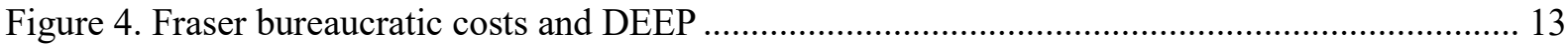

Figure 5. Legal time limit for environmental permitting procedures .................................................. 14

Figure 6. Legal versus average duration of environmental permitting procedures for low environmental impact facilities

Figure 7. Legal versus average duration of environmental permitting procedures for high environmental impact facilities

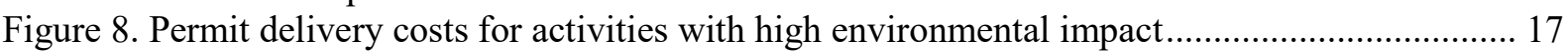

Figure 9. Permit delivery costs for activities with low environmental impact.................................... 18

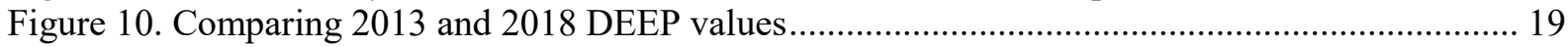

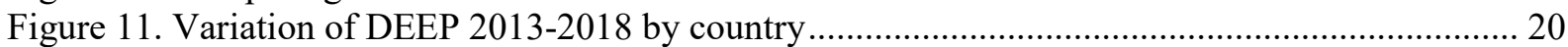

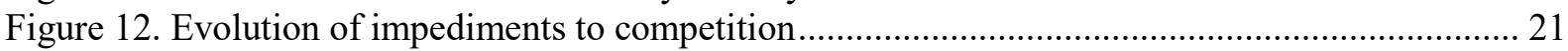

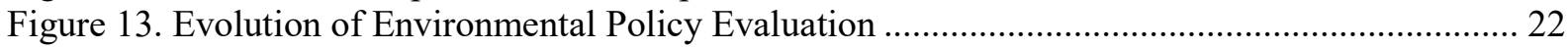

Figure 14. Correlation between the evolution of DEEP and the evolution of EPI (2012-2018) .......... 24

Figure 15. Correlation between the evolution of DEEP and PMR (2013-2018) ................................. 25

Figure B.1. Correlation between Environmental Permitting Cost and Environmental Policy

Stringency..... 29

\section{Boxes}

Box 1. National efforts to simplify and improve environmental policy procedures ..... 


\title{
Assessing the efficiency of environmental policy design and evaluation: Results from a 2018 cross-country survey
}

\author{
By Clara Berestycki and Antoine Dechezleprêtre ${ }^{1}$
}

\section{Introduction}

1. More ambitious environmental policies in multiple domains are necessary to enable the transition to a greener economy. However, there is concern that such policies weigh on sustained economic growth through different channels. First, environmental policies may distort market competition. Such concerns arise because environmental policies are prone to generate differences or asymmetries in regulatory stringency across firms. For example, regulation may apply to specific firms only while others are exempt, or some sectors may face stricter pollution standards than others. Secondly, environmental policies may impose transaction and administrative costs related to permitting and licensing. This procedural complexity creates situations of imperfect information detrimental to markets and can lead to increased barriers to entry in concerned sectors. However, conducting regular policy evaluations which take these features into account may enable governments to regularly improve the design of environmental policies while providing easily accessible information on administrative requirements associated with environmental policies may enhance transparency.

2. To measure the extent to which public policies promote or inhibit competition in markets, the OECD has been conducting a periodic exercise to quantify and compare anticompetitive product market regulation (PMR) since 1998. However, the PMR indicators do not include information on environmental policies, permitting and licensing, largely due to the complexity and the challenge related to quantifying and comparing them. Given the increasing attention to the design of environmental policies, current efforts seek to gradually fill this gap by building an indicator which could be labelled as the "environmental policy" complement to the $\mathrm{PMR}^{2}$ : the Indicator of Design and Evaluation of Environmental Policies (DEEP).

\footnotetext{
${ }^{1}$ Antoine Dechezleprêtre (Antoine.Dechezlepretre@oecd.org) is a Senior Economist at the OECD Economics Department and the OECD Environment Directorate. Clara Berestycki was an intern at the OECD at the time of writing this paper. The authors thank Susana Escária, Ana Esmeralda Martinez Saez and Francisco Aleza, Ohad Carny and Marc Luhan for their helpful insights on the evolution of Portuguese, Spanish, and Israeli legislation respectively. The authors are grateful to Shardul Agrawala (OECD Environment Directorate), Tomasz Koźluk, Giuseppe Nicoletti and Monika Grzegorczyk (all from the OECD Economics Department) for many useful comments, and to Celia Rutkoski for excellent editorial support.
}

${ }^{2}$ Koźluk, 2014. 
3. The DEEP indicator was created in 2013 as an annex to the OECD's flagship Product Market Regulation (PMR) questionnaire. This report presents the results of the second wave of the DEEP, which took place in 2018, this time independently from the PMR. ${ }^{3}$ In both rounds, environmental policy experts from each national government answered the questionnaire.

4. In its initial 2013 vintage, the DEEP indicator was called BEEP (indicator of Burdens on the Economy due to Environmental Policies). The BEEP indicator was later renamed DEEP (Design and Evaluation of Environmental Policies indicator), in order to better reflect its underlying structure, and in particular its focus on policy evaluation. The same four sections of the 2013 BEEP indicator make up the 2018 DEEP indicator, making them directly comparable.

5. The DEEP indicator measures two potential market burdens generated by environmental policies and the extent to which environmental policy evaluations take those into account ${ }^{4}$. The first section of the indicator measures the administrative costs associated with environmental policies. The second section assesses to which extent environmental policies directly inhibit competition. Lastly, the third and fourth sections of the indicator analyse the quality of ex-ante and ex-post environmental policy evaluation, in particular to what extent such policy evaluations consider how environmental policies affect markets.

6. The aim of DEEP is to create a cross-country indicator enabling the comparison of environmental policy design across countries. However, environmental policies are complex and multidimensional: within a country, policy instruments can vary significantly across sectors, regions, and types of industrial facilities. As any country-level indicator, the DEEP index does not reflect this complexity but instead measures average burdens at the national level of the existing environmental policy package.

7. This note is organised as follows. Section 2 briefly presents how the DEEP indicator is constructed and outlines changes from the 2013 version. Section 3 reports the results of the 2018 DEEP indicator and analyses the correlation between DEEP and other regulatory burdens indicators. Section 4 analyses how the DEEP 2018 indicator compares to the 2013 version and how the evolution of the DEEP correlates with the evolution of other environmental and regulatory burdens indicators. It provides some preliminary analyses of the reasons behind significant changes in DEEP across the two waves.

\section{DEEP Indicator Structure}

\subsection{Definition and scoring of DEEP sub-indicators}

8. Figure 1 shows the different components of the DEEP indicator, as outlined in the introduction:

\footnotetext{
${ }^{3} \mathrm{~A}$ new section on the treatment of waste was included in the 2018 questionnaire. This section is currently not included in the DEEP indicator.

${ }^{4}$ Nicoletti et al., 2000.
} 
Figure 1. Structure of the BEEP and DEEP indicators

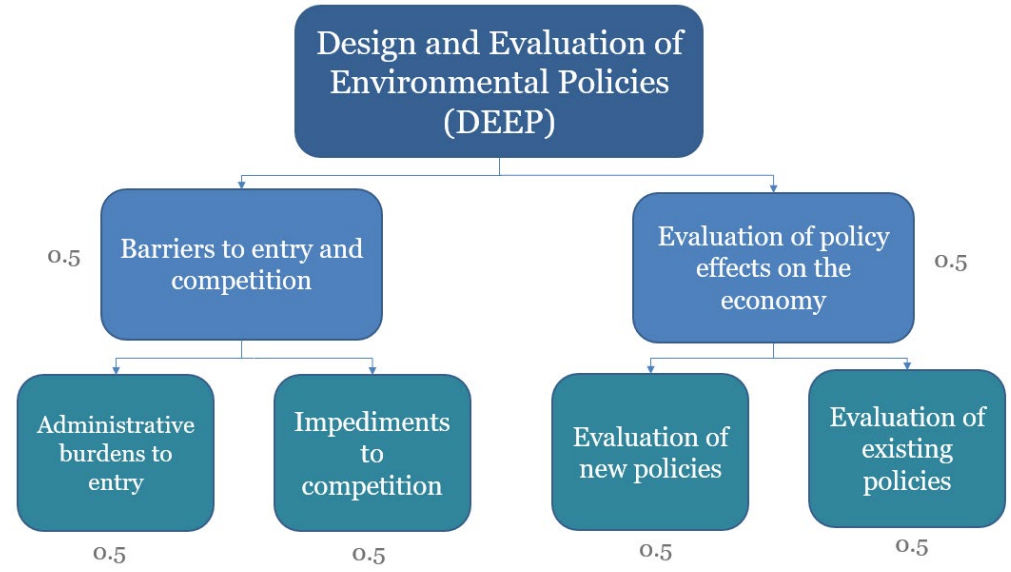

Note: Aggregation uses equal weights of subcomponents. The 2018 DEEP indicator has exactly the same structure as the 2013 BEEP indicator.

Source: Koźluk, 2014

9. Questions selected to form the indicator are grouped according to the following themes ${ }^{5}$ :

- Barriers to entry and competition: the aim is to capture direct characteristics of environmental policies and permits that may inhibit or slow down entry and provide an advantage to incumbents. These include:

- Administrative burdens associated with permitting/licensing procedures - this component groups questions attempting to capture the administrative complexity related to permitting, which is faced by entrepreneurs when opening a plant or a company ${ }^{6}$. Questions include the legal limit on the administrative response to a request for a permit/license, ease of access to all necessary information, forms to be filled-in, etc.

- Direct impediments to competition - this component aims at capturing the aspects of environmental policies that can directly discriminate against new entrants. The most common forms are vintage differentiated regulations (VDRs), where new entrants may face stricter environmental norms than incumbent firms and subsidies and tax incentives. Tax and subsidy incentives can be more beneficial for incumbents than for young firms, for instance by being based on past performance or if young firms tend not to have profits. Due to the potentially wide and multidimensional character of such policies, questions for several selected industries are included.

- Evaluation of economic effects of environmental policies in policymaking: the focus is on the role of potential effects on competition, entry and more generally economic outcomes in procedures applied in the environmental policy making process, ex ante and ex post. In this sub-indicator, laxer and less transparent requirements and practise in evaluation of economic effects are considered as

\footnotetext{
${ }^{5}$ Koźluk, 2014.

${ }^{6}$ The idea resembles that of License and permit systems and Administrative burdens in the Barriers to entrepreneurship indicators in the Product Market Regulation Indicator structure - which focuses on regulations increasing the cost of entry.
} 
"bad", as potentially leading to higher burdens to economic activity. The two areas include:

- Evaluation of new policies - this component summarises information on the process of environmental policy making. The focus is on requirements to conduct ex ante analysis of various economic consequences of new policy proposals and the choice of tools to achieve environmental goals.

- Evaluation of existing policies - this component attempts to capture the degree to which economic considerations are taken into account in reviewing the entire setup of existing policies, regarding ex post evaluations of policies and policy setups, transparency and the responsiveness to stakeholders.

10. Two criteria define which questionnaire responses go into the indicator: (1) relevance and interpretability with respect to the initial question of interest and (2) the response rate. Question responses are scored on a scale from 0 to 1.0 is the best possible score, signalling policies or dispositions most friendly to competition, and 1 is the worst possible score ${ }^{7}$. Questions are then aggregated into the relevant sub-indicators and rescaled from 0 to 6.0 is the best score. Aggregating the four sub-indicators with equal weights yields the final indicator.

11. In the 2018 round of the DEEP questionnaire, countries had the opportunity to change their 2013 answers. The 2013 BEEP indicator has been recalculated to reflect these modifications. Furthermore, the computation formula of the DEEP indicator was adjusted to better weigh responses in the computation of sub-indicators. Lastly, the 2018 DEEP questionnaire includes new questions that were added to the indicator. The 2018 DEEP indicator thus includes more questions than the 2013 BEEP. The detailed scoring and aggregation procedures by sub-indicator and the list of questions are available in Appendix E.

\subsection{A high response rate}

12. Out of 37 countries who received the 2018 questionnaire, 32 countries replied at least partially ( $86 \%$ of countries). Some countries did not reply due to a lack of resources. Of these 32, it was possible to compute the indicator for 29 countries ( $78 \%$ of countries). The questionnaire was too incomplete for the other three.

13. Out of the countries that replied, the average completion rate is high (on average, $90 \%$ of questions were filled in). Detailed response rates for each country are provided in Appendix F, Table AF1. The response rate differs among sub-indicators and across questions. For example, the answer rate is lowest for questions on administrative burdens concerning the average duration and cost to obtain permits for firms. Even though this information would be a valuable metric to compare policies across countries, many countries were unable to precisely answer this question because of a lack of data. The challenges faced by countries in answering these questions highlight the institutional complexity associated with environmental permitting. For example, Israel mentions a difference in permitting time for hazardous materials and air pollutants, making it difficult to compute an average duration at the country level.

\footnotetext{
${ }^{7}$ The construction of the BEEP and DEEP indicators seeks to mirror that of the PMR indicator.
} 


\section{The DEEP indicator -2018 results}

\subsection{Overall Indicator Results}

14. Figure 2 represents the ranking of countries according to their 2018 DEEP score for the 29 countries whose response rate was high enough to enable the construction of the indicator. The index is broken down by sub-indicator for each country. On a scale from 0 (best) to 6 (worst), the minimum score is 0.62 (Korea) while the maximum score is 3.31 (Italy). The distribution of scores is relatively tight: almost $70 \%$ of countries score between 1.50 and 2.50. The countries scoring the best on the DEEP indicator are Korea, Israel, Spain, and Switzerland. The countries scoring the worst on the DEEP indicator are Italy, Luxembourg, Greece, and Sweden.

15. Among sub-indicators, countries scored best in Evaluation of New Policies, ranging from 0 for Mexico, Israel, and Korea to 1.17 for Italy (on a scale from 0 to 1.5). Countries scored second best in Direct Impediments to Competition, which is also the score that varies the least among countries. This sub-indicator ranges from 0 for Denmark, Ireland, Latvia, and Switzerland to 1 for the Czech Republic. Countries scored third best in Evaluation of Existing Policies. Finally, countries scored the worst in the sub-indicator Administrative Burdens. The score of the sub-indicator Administrative Burdens is also the one that varies the most among countries, ranging from 0.20 for Korea to 1.41 for Canada. Detailed values for the total DEEP indicators and for individual sub-indicators for each country can be found in Annex D (Table AD1).

Figure 2. DEEP 2018 values

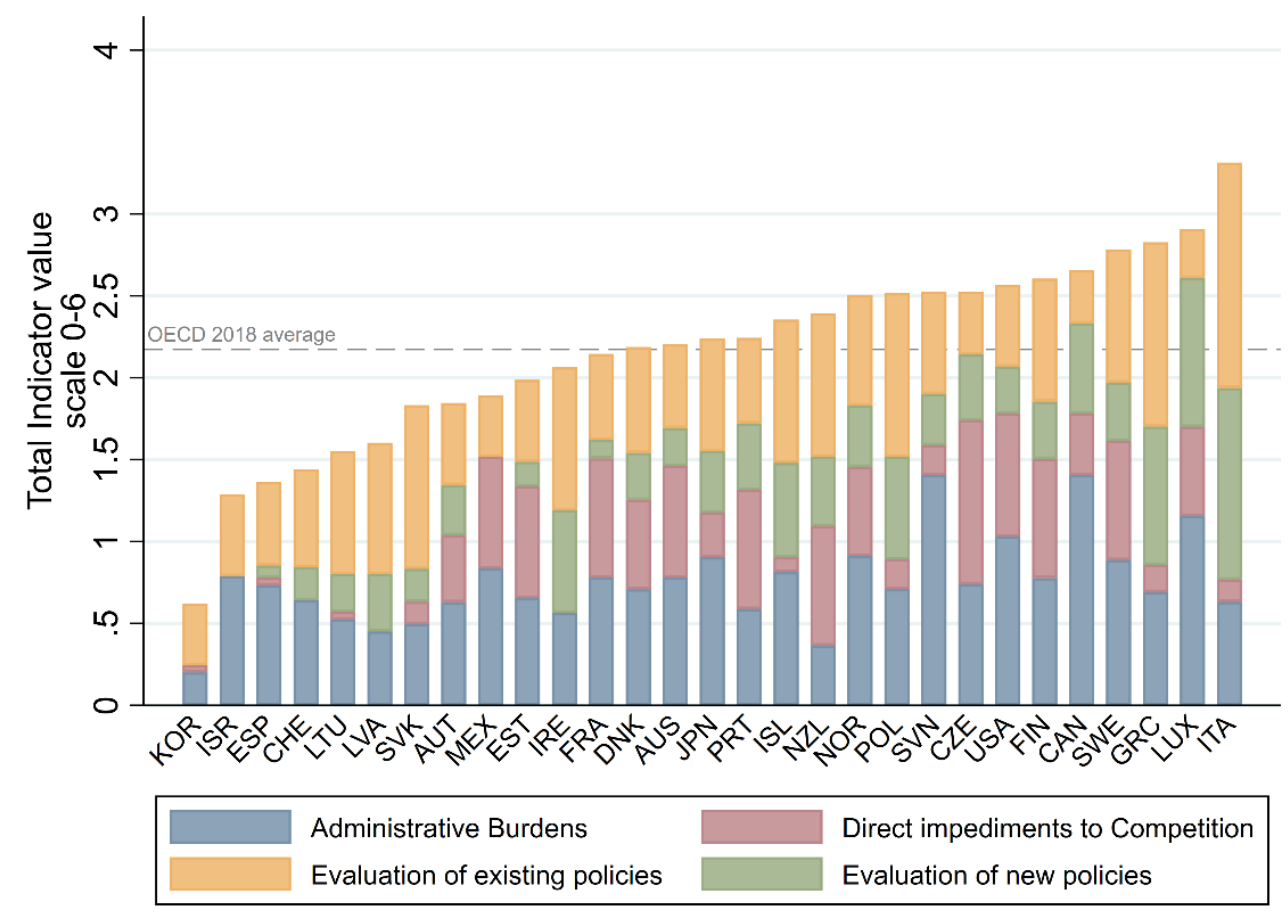




\subsection{Correlation of DEEP 2018 with other environmental and regulatory indicators}

\subsubsection{DEEP and environmental indicators}

16. Preliminary results reinforce the 2014 conclusion according to which high burdens to the economy are not a necessary feature of more stringent environmental policy ${ }^{8}$. The DEEP indicator values were compared to three other environmental indicators: the EPS (environmental policy stringency) indicator computed by the OECD, the Ecological footprint per country (available for the year 2014), and the Yale Environmental Performance Index 2018 (EPI). The EPS indicator is a proxy for environmental policy stringency measured as the implicit or explicit cost of environmentally harmful behaviour (i.e. taxes on emissions, air pollution concentration standards, subsidies to renewable energy production). The EPI and Ecological Footprint indicators belong to a different family of indicators as they measure environmental performance. The EPI indicator measures environmental quality by building scores for ecosystem vitality (ex: biodiversity protection, fishing stocks) and environmental health (ex: emission levels, water quality). The higher the EPI, the better the environmental quality. Developed by the Global Footprint Network and measured in global hectares per capita, the global footprint score tracks how much biologically productive area it takes to provide for all the demand from citizens of a given country (Global Footprint Network, 2018).

17. The DEEP indicator does not significantly correlate to any of the three selected environmental indicators. Figure 3 shows the lack of correlation between EPS and DEEP. This lack of correlation comforts the conclusions from the 2013 wave. High environmental stringency (measured by EPS) and high environmental quality (measured by EPI) are not necessarily associated with policies imposing high burdens on the economy. Correlation coefficients are listed in Table A1 in Annex A.

Figure 3. Correlation between the EPS and the DEEP indicator

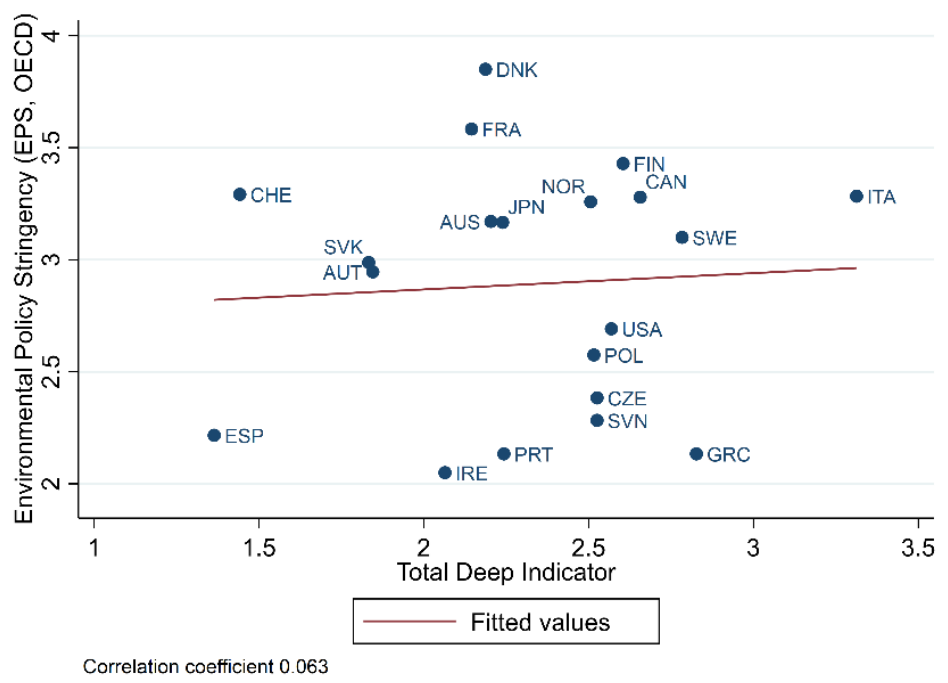

Note: Not all countries are represented on this graph because EPS indicators were computed only for a selected range of countries. Most recent values for EPS are 2012, 2013, or 2015 depending on the country.

\footnotetext{
${ }^{8}$ Koźluk, 2014.
} 


\subsubsection{Burdens on the economy generated by environmental policy correlate with overall regulatory burdens}

18. Figure 4 shows the correlation between the DEEP indicator and the Fraser indicator of "Bureaucratic Costs". This indicator measures the risk that normal business operations become more costly due to the regulatory environment (Fraser Institute, 2018). This clear positive correlation between both indicators suggests that economic burdens from environmental policies are partly a reflection of general bureaucratic costs (See Annex A Table A2 for correlation coefficients with sub-components of the Fraser indicator). Discussions held with Spain, Portugal, and Israel further suggest that burdens on the economy generated by environmental policy are not necessarily specific to the environmental sector but relate to all policies more generally.

19. The DEEP indicator was further compared to other regulatory indexes from the Fraser Institute, the World Economic Forum (WEF), the World Bank, and the OECD. Even though they are not statistically significant, the sign of the correlation coefficients between the DEEP indicator and the World Bank indicator Ease of Doing Business confirm that a low DEEP value is correlated to a favourable business environment (the lower the DEEP indicator, the better the country scores on the Ease of Doing Business index). Correlation results are reported in Table A3 in Annex A.

20. Most of the correlations between DEEP values and these other regulatory and business environment indicators are not statistically significant. As shown in Table A5 in Annex A, there is no cross-sectional correlation between 2018 DEEP values and the 2018 vintage of the OECD Product Market Regulation indicator. This result is coherent with conclusions drawn from the previous vintage of the $\mathrm{DEE}^{9}$. Similarly, correlations between the DEEP indicator and the World Economic Forum Competitiveness indicator (reported in Table A4 in Annex A) are generally small and insignificant. The World Economic Forum Competitiveness indexes reflect the view of Business Executives, a different perspective from that of the DEEP and of the Ease of Doing Business indicator. Furthermore, the WEF indexes focus on competitiveness, which varies greatly between different sectors in contrast to bureaucracy costs and other administrative burdens.

21. Thus, the DEEP indicator could capture some aspect of administrative burdens at the national level but not necessarily competitiveness aspects. All in all, the lack of crosssectional correlation of the DEEP indicator with these different indexes suggests that the DEEP indicator captures dynamics that are proper to environmental policy rather than simply the global business and regulatory environment.

\footnotetext{
${ }^{9}$ Koźluk, 2014.
} 
Figure 4. Fraser bureaucratic costs and DEEP

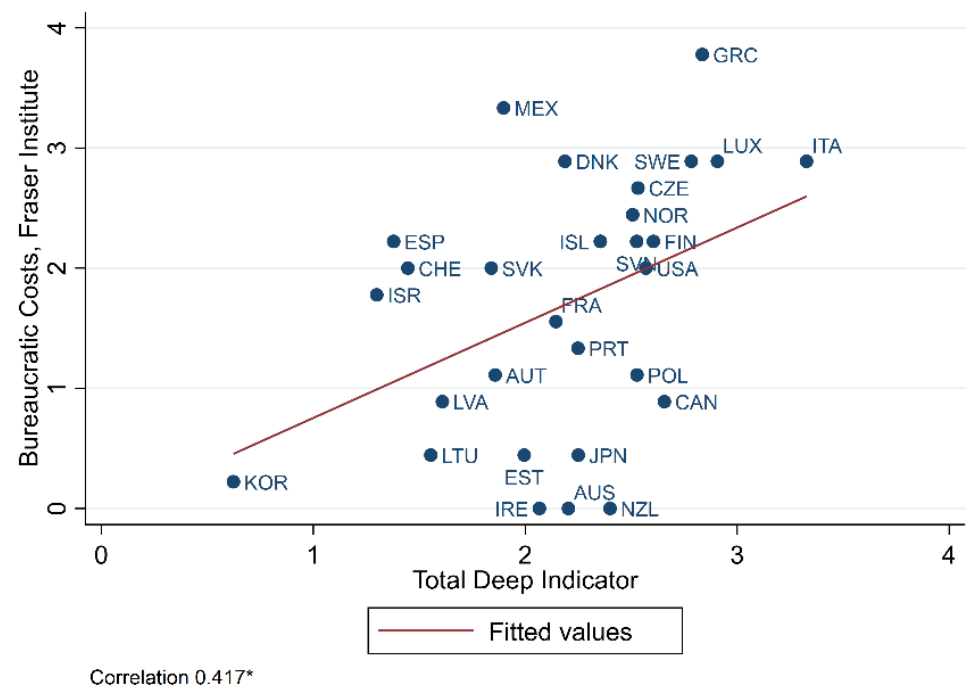

Note: The Fraser Bureaucratic Costs indicator is rescaled from 0 to 10 , with 0 indicating the lowest costs and 10 indicating the highest costs. Decreasing values for DEEP between 2013 and 2018 were spearheaded by a small number of countries.

\subsection{A look inside in the DEEP: Comparing environmental permitting procedures}

22. Environmental permitting is a crucial tool of environmental policy, in particular for pollution prevention. However, the complexity of environmental permitting and licencing can generate substantial market distortions. The sub-indicator "administrative burdens" of the DEEP analyses three dimensions of environmental permitting and licencing: procedure complexity, timing, and cost. Identifying and going through the permit application process can be difficult and time-consuming. The questionnaire thus seeks to assess progress towards an integrated environmental permitting system, which is considered best practice by the $\mathrm{OECD}^{10}$. This section presents a more in-depth analysis of the other two components: time and costs associated with environmental permitting procedures. The underlying reasoning is as follow: the higher the administrative costs, and the longer the process, the heavier the burdens of environmental permitting for firms.

\subsubsection{How long does it take to obtain an environmental permit?}

Permitting procedures are on average $45 \%$ longer for high impact environmental facilities

23. Figure 5 presents average legal permitting procedure times for both low and high environmental impact facilities. Austria, Canada, Denmark, Finland, Iceland, and Norway have no legal time limits for either types of facilities. France and Greece have limits for procedures for high-impact facilities but not for low-impact facilities, while Sweden has limits for low-impact but not for high-impact. Korea has the shortest permitting procedure timing of our sample.

\footnotetext{
${ }^{10}$ OECD, 2007.
} 
24. In our sample, procedural time is on average 88 days for low-environmental impact facilities. This duration is about twice as short as for high-environmental impact facilities, for which the average time is 189 days ${ }^{11}$. This significant difference highlights a form of environmental policy stringency. Luxembourg, Austria, and Poland boast significant differences (more than 100 days) in permitting times for low and high environmental impact procedures. On the other hand, the Czech Republic, Spain, Japan, Mexico, and Portugal have the same legal time limit for both types of facilities.

25. Consequently, the variation in our sample for legal time limits of environmental permitting procedures is high, even among European countries (see Figure 5). The standard deviation for legal time limits is 74 days, indicating that procedure time for individual countries deviates on average by 2.5 months from the OECD average procedure duration.

Figure 5. Legal time limit for environmental permitting procedures

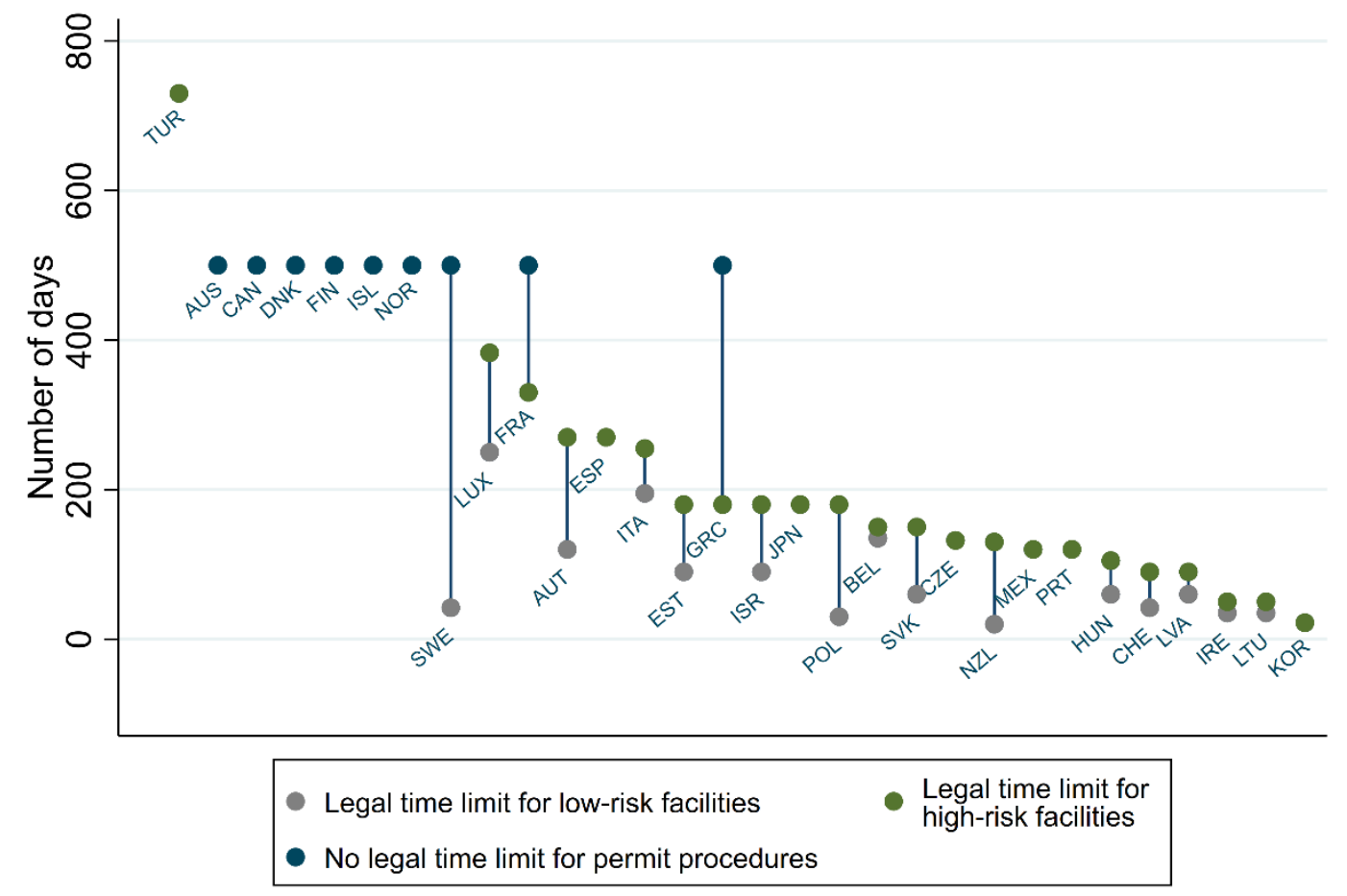

Average legal time limit for environmental permits for low-risk facilities in our sample: 189.00 days Average legal time limit for environmental permits for high-risk facilities in our sample: 104.00 days

Source: BEEP 2018 Questionnaires, questions QA3.1.10a and QA3.1.10b.

Obtaining an environmental permit takes on average 25 days less than the legal time limit

\footnotetext{
${ }^{11}$ These numbers are calculated for countries that declare having a legal time limit. There are 20 observations for low-impact facilities and 11 for high-impact facilities. The source for these calculations is question QA3.1.10a and QA3.1.10b in Table A3.A "Administrative Burdens".
} 
26. The DEEP questionnaire also allows for a comparison between the legal maximum and the effective procedure time. Contrasting these two measures gives an indication of the functioning of relevant governmental authorities. An average time higher than the legal time limit may highlight some issues in the treatment of environmental permits. In contrast with questions on legal time limits ${ }^{12}$, the questions on average procedure length ${ }^{13}$ were among the least answered in the questionnaires, with answer rates at $44 \%$ for low-impact facilities and $56 \%$ for high-impact facilities ${ }^{14}$. This lack of data highlights the difficulty for countries to compute these statistics because these questions span different sectors (water, waste, air pollution) and different facility types. Firm-level data could prove interesting to reinforce this analysis.

27. The average actual permitting time for all types of firms is lower than the legal limit by $15 \%$ at 116 days ${ }^{15}$ against 135 days. This result suggests that legal-time limits are coherent with actual permitting delivery times.

28. Figure 6 contrasts legal and actual permit delivery times for low-impact facilities while Figure 7 shows these numbers for high impact facilities. The difference between legal and actual permit delivery time is the same for high and low-impact facility (approximately 15 days). Table $\mathrm{AC} 1$ in Appendix $\mathrm{C}$ presents summary statistics on legal and average environmental procedure lengths.

Figure 6. Legal versus average duration of environmental permitting procedures for low environmental impact facilities

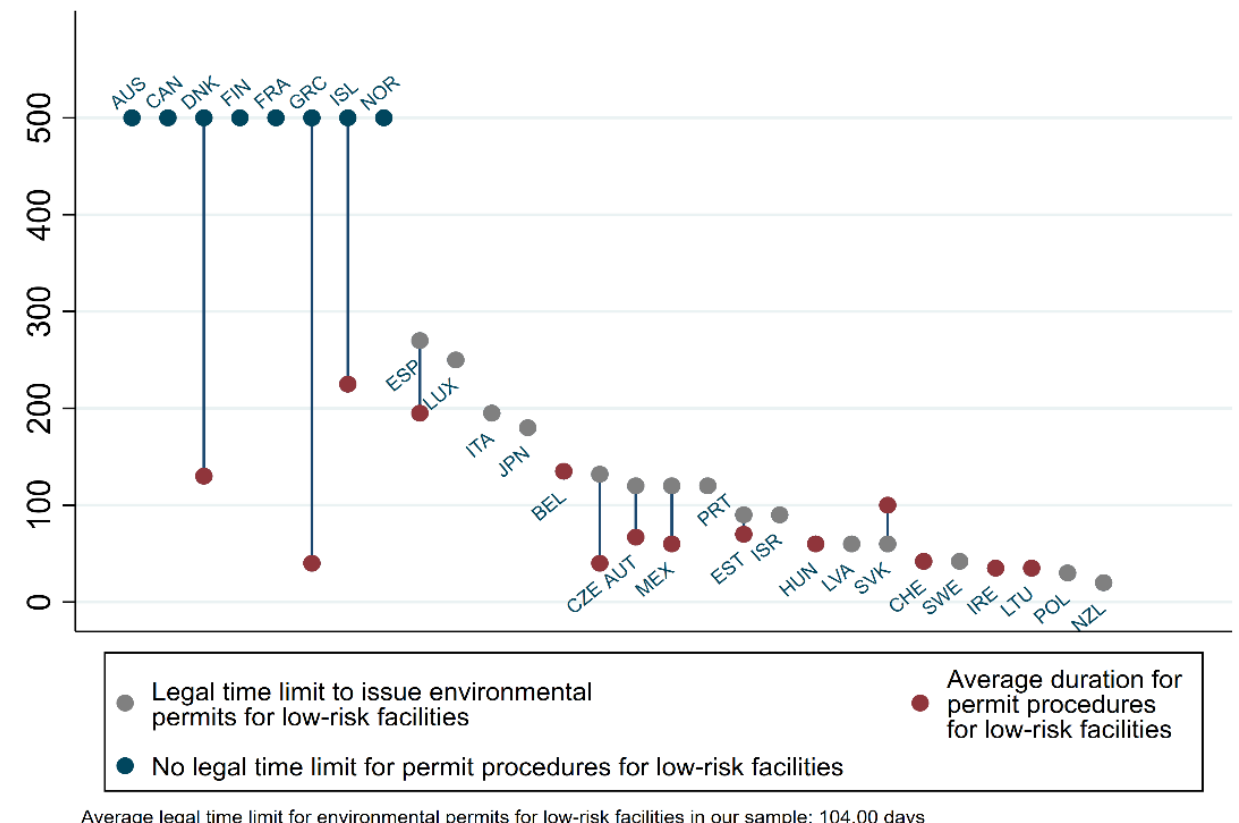

Average legal time limit for environmental permits for low-risk facilities in our sample: 104.00 days
Average mean duration of environmental permit obtention procedures for low-risk facilities in our sample: 88.00 days

${ }^{12}$ QA3.1.10a and QA3.1.10b in Table A3.1 "Administrative Burdens".

${ }^{13}$ QA3.1.13a and QA3.1.13b in Table A3.1 "Administrative Burdens".

${ }^{14}$ These percentages are calculated for countries that replied at least partially to the BEEP questionnaire.

${ }^{15}$ This number is calculated only for countries that declare a legal time limit. This reduces our sample to

11 countries for the calculation of average time of permitting procedures. 
Figure 7. Legal versus average duration of environmental permitting procedures for high environmental impact facilities

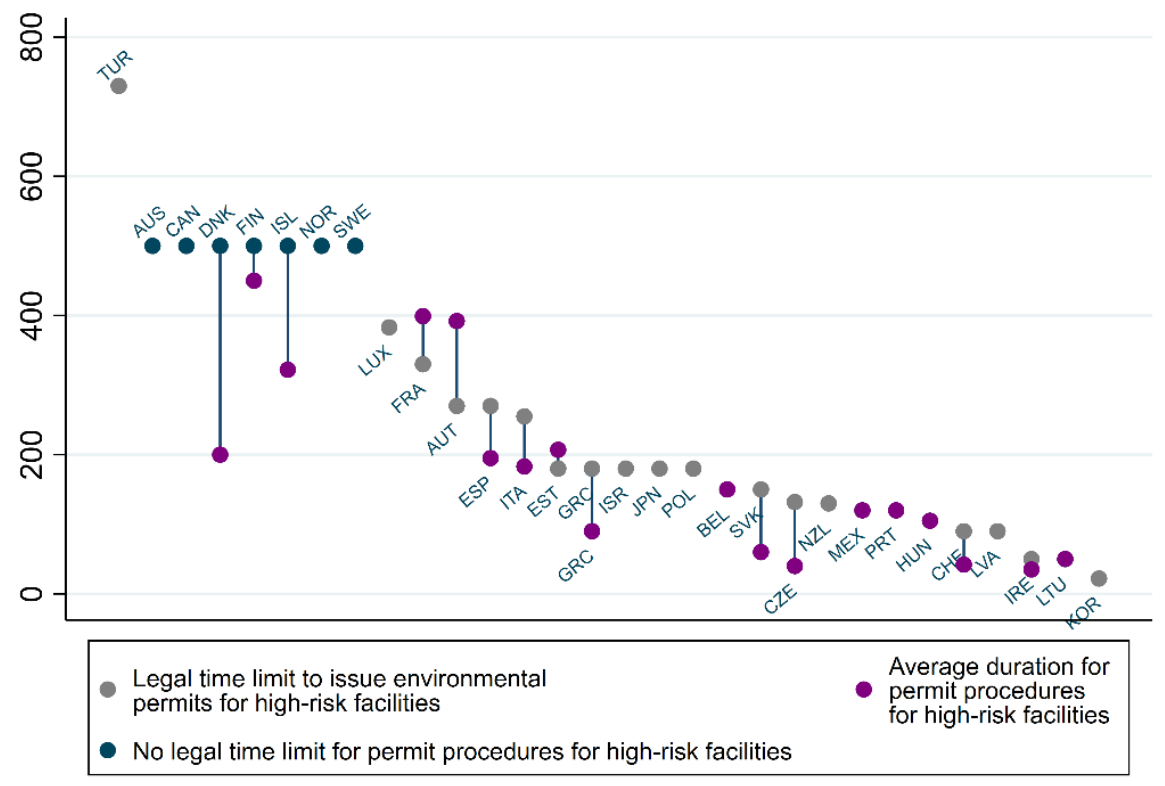
Average legal time limit for environmental permits for high-risk facilities in our sample: 189.00 days
Average mean duration of environmental permit obtention procedures for high-risk facilities in our sample: 175.00 days

\subsubsection{How much does an environmental permit cost?}

Costs party reflect the polluter-payer principle: environmental permits for high impact facilities cost $60 \%$ more than those for low-impact facilities

29. The questionnaire maps out the costs to be paid to the relevant governmental authority to obtain environmental permits ${ }^{16}$. This question does not cover the potential legal costs that firms may have to take on. The very low response rate, $50 \%$, is similar to that of the question on average permit delivery time for similar reasons.

30. The data collected (17 and 18 countries for low and high facilities respectively) is extremely heterogeneous. Because of the diversity of permits covered by this question, some countries chose to report ranges of costs (see the grey bars on Figures 8 and 9). Ireland reports the highest environmental permit cost at $€ 30,000$ while France, Denmark, and Austria report having no environmental permit cost. This range reflects the permit costs for high environmental impact firms (Figure 8). For firms with a low environmental impact, permitting costs range from 0 for France, Denmark, and Austria to $€ 6,400$ for Ireland (Figure 9). This large range most likely reflects in part different interpretations of the question by countries. Summary statistics on permit costs and environmental permitting procedures can be found in Table C A.1 in Appendix C.

31. The average costs for high environmental impact facilities is $€ 3,767$ compared to $€ 1,374$ for low environmental impact facilities ${ }^{17}$. This indicates that entry costs are higher

\footnotetext{
${ }^{16}$ Question QA3.1.14, not included in the indicator because of low response rates.

${ }^{17}$ This significant difference is in part driven by Ireland, which has significantly higher permitting costs for high impact facilities. If Ireland is taken out of the sample, the average costs for high impact facilities drops to $2519 €$.
} 
for firms with a higher environmental impact. The polluter-payer principle is thus to some extent enforced for environmental permits in our sample. To analyse market distortions on a more granular level, an analysis should be conducted at the sector level to understand if firms with the same level of environmental externality face the same permitting costs.

32. However, there is no correlation between permitting costs and overall environmental policy stringency, reflecting the diversity of environmental policy tools chosen by countries (as shown in Figure BA1 in Annex B). For example, both the Czech Republic and Ireland score low on the OECD Environmental Policy Stringency Indicator ${ }^{18}$ but the Czech Republic has low permitting costs while Ireland has the highest costs of the sample.

Figure 8. Permit delivery costs for activities with high environmental impact

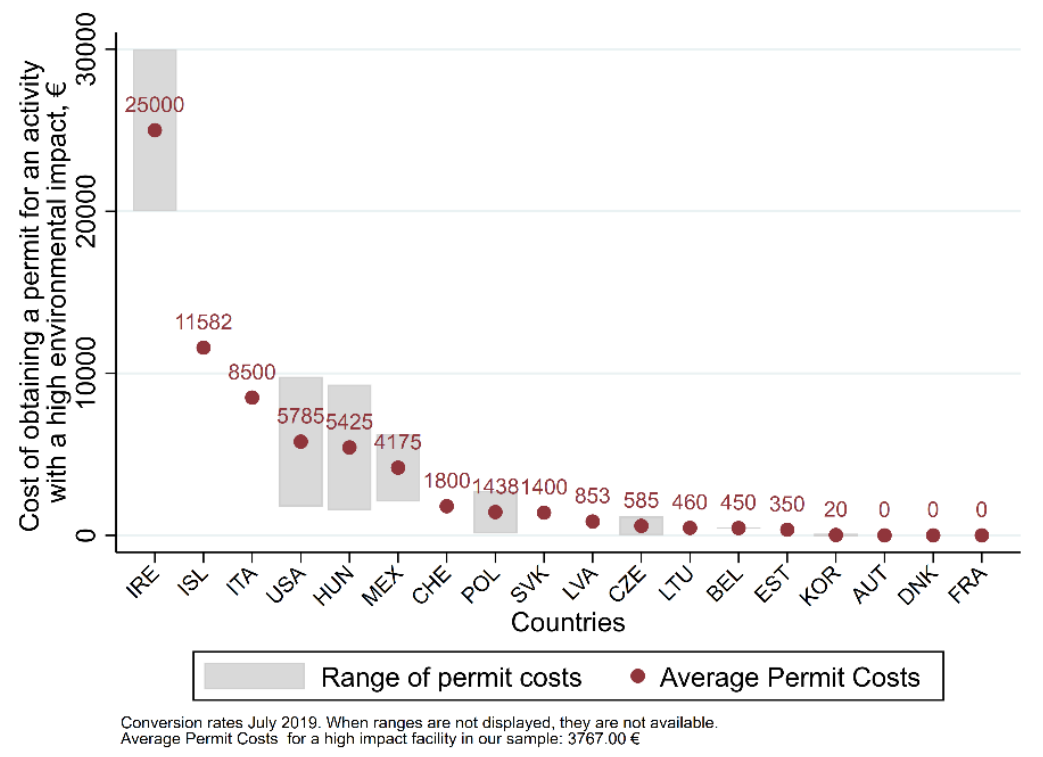

${ }^{18}$ Environmental Policy Stringency Indicator for Ireland: 2.05, for the Czech Republic 2.38. The scale goes from 0 to 6 with 6 being the most stringent. Source: Koźluk (2014). However, this lack of correlation could be linked to the restriction of the Environmental Policy Stringency Indicator to climate and air pollution. 
Figure 9. Permit delivery costs for activities with low environmental impact

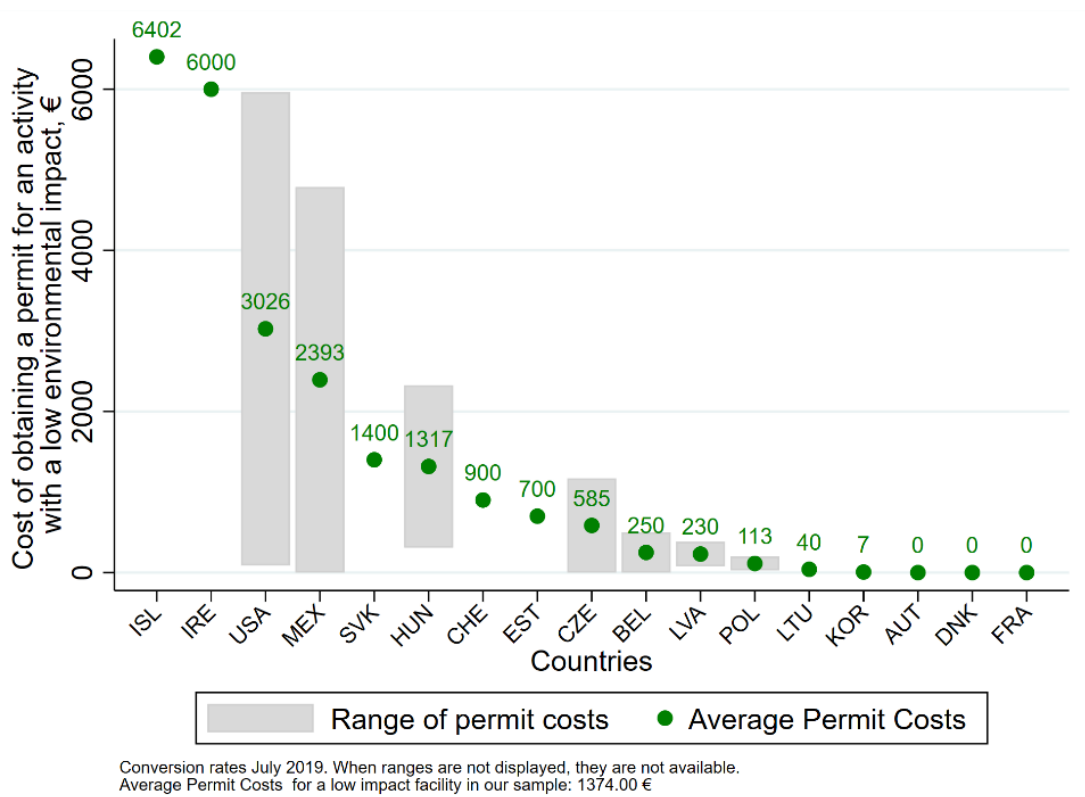

\section{Comparing 2013 and 2018 DEEP values}

\subsection{Overall changes}

33. The OECD average for DEEP is lower in 2018 than in 2013, going from 2.64 to 2.17 , which corresponds to or a $16 \%$ decrease. Table 1 presents the comparison of DEEP 2013 and 2018. Looking at the changes at the sub-indicator level, the variation in the DEEP is mostly due to improvements in the sections concerning direct impediments to competition and evaluation of new policies, which respectively went down $24 \%$ and $28 \%$ between 2013 and 2018 (See Table 1). The sub-indicator Evaluation of existing policies and Administrative Burdens are the most stable across the two rounds of the DEEP, decreasing respectively by $13 \%$ and $15 \%$.

Table 1. Comparing DEEP 2013 and 2018 by sub-indicator

\begin{tabular}{l|c|c|c}
\hline & 2013 Indicator & 2018 indicator & Change \\
\hline Administrative Burdens & 3.47 & 2.96 & $-15 \%$ \\
\hline Direct Impediments to Competition & 1.98 & 1.52 & $-24 \%$ \\
\hline Evaluation of policies (new) & 2.04 & 1.48 & $-28 \%$ \\
\hline Evaluation of policies (existing) & 3.06 & 2.66 & $-13 \%$ \\
\hline Total Indicator & $\mathbf{2 . 6 4}$ & $\mathbf{2 . 1 7}$ & $\mathbf{- 1 8 \%}$ \\
\hline
\end{tabular}

Note: Sub-indicators are scaled from 0 to 6 . The final indicator is the sum of all four sub-indicators and is scaled form 0 to 6. DEEP 2013 values are reported only for countries also included in the 2018 edition for comparability. 
34. Figure 10 presents DEEP values for countries in 2013 and 2018 and Figure 11 directly shows the change in DEEP values for each country. Both are ordered by the magnitude of the change between 2013 and 2018. Only three countries experience an increase in the value of the indicator. DEEP values are stable for most countries but a sharp drop in the value of the DEEP is observed for some countries. DEEP values for Korea, Spain, Israel, Iceland, Portugal and New Zealand decrease by more than 30\% (see Figure 11). On the other hand, DEEP values only increased significantly for Austria.

35. Strikingly, these large changes to the value of the DEEP indicators alter and sometimes reverse the 2013 ranking of countries. Thanks to a decrease of more than $50 \%$ of its DEEP value, Spain goes from scoring the worst of OECD countries on the DEEP to scoring third best (See Figure 10). The ranking of Israel changes in a similar fashion, from third worst in 2013 to second best in 2018. Consequently, countries with stable DEEP values such as Canada fall in the ranking.

Figure 10. Comparing 2013 and 2018 DEEP values

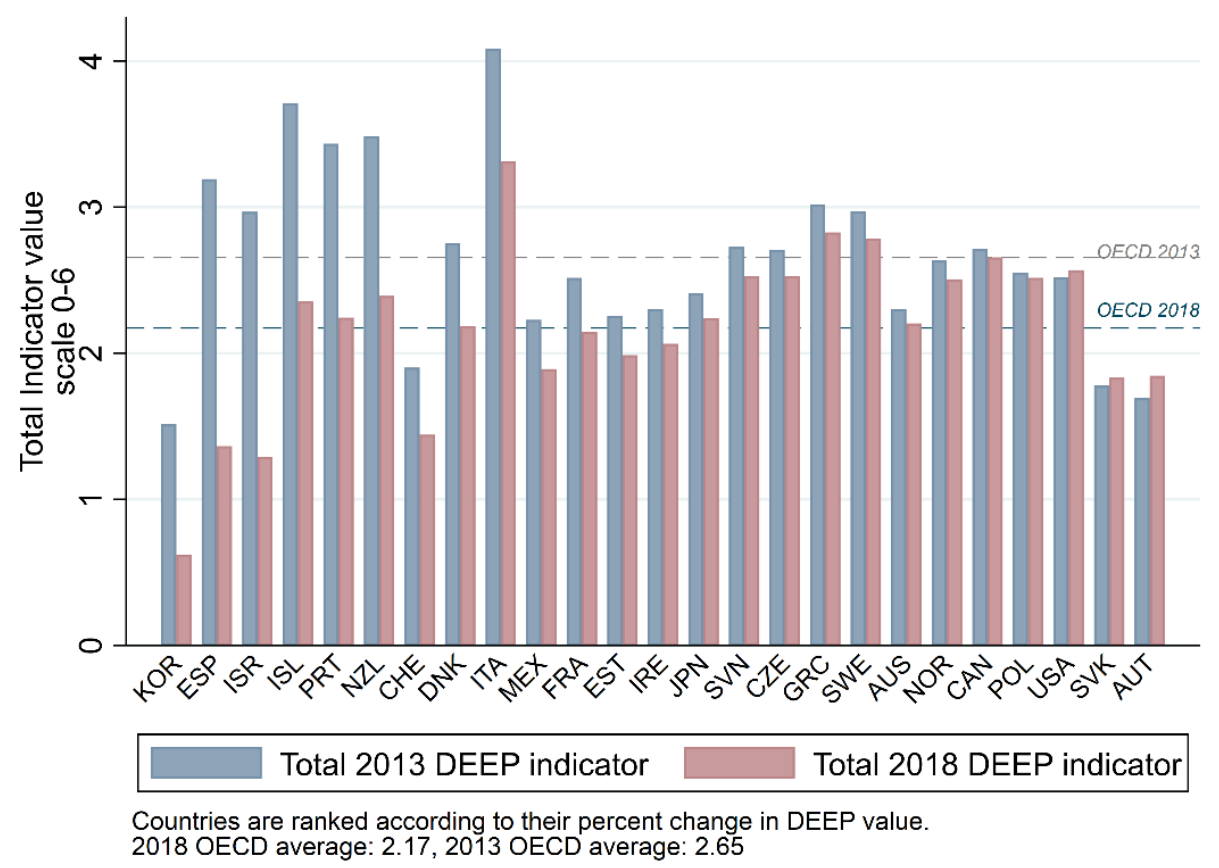

Note: Values are not represented for Latvia, Lithuania, Finland, and Luxembourg because no DEEP indicator was computed for these countries in 2013. The 2013 DEEP average is only computed for countries with a final 2018 DEEP indicator. 
Figure 11. Variation of DEEP 2013-2018 by country

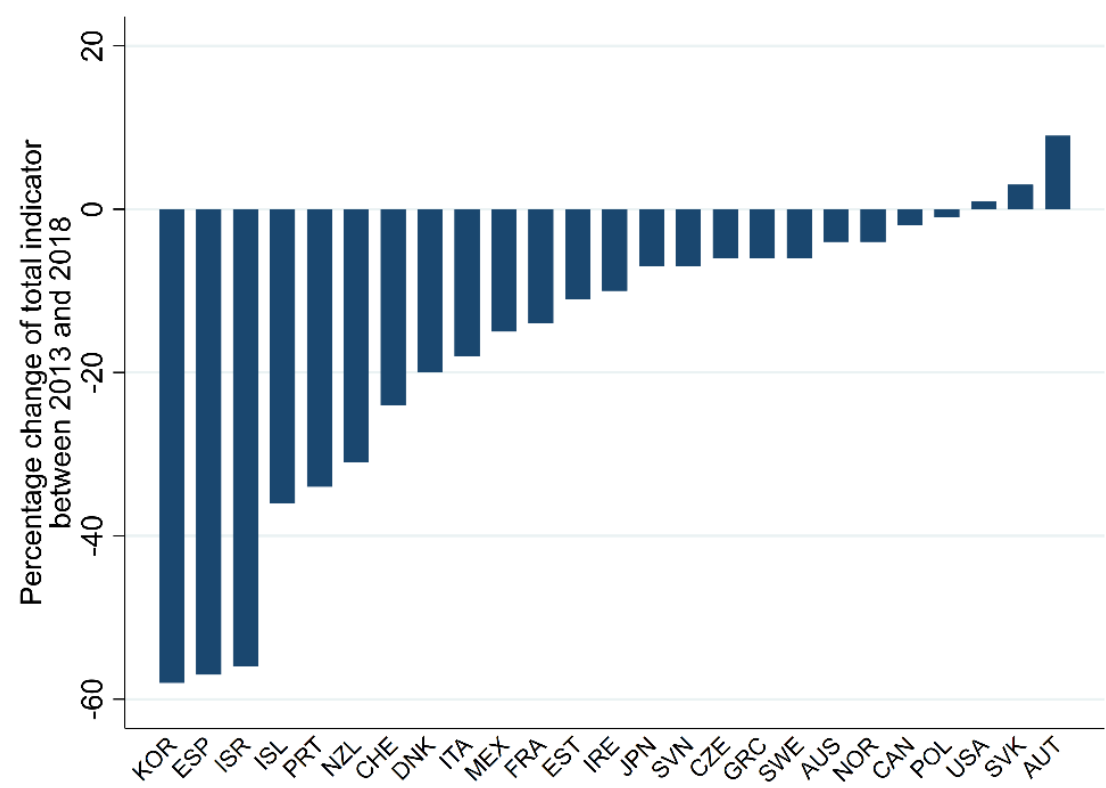

Note: This graph represents the change of DEEP value between 2013 and 2018 for countries (in percentage) ranked from the biggest decrease to the biggest increase. For example, the DEEP value for Austria increased the most between 2013 and 2018.

\subsection{Between 2013 and 2018 , environmental policy became more compatible with competition}

36. As indicated in Table 1, the sub-indicator Direct Impediments to Competition decreased sharply across the two DEEP vintages. The sub-indicator "direct impediments to competition" measures if environmental policy instruments create market distortions. The sub-indicator covers market-based instruments functioning through prices, such as subsidies, tax breaks and offset purchases but also non-market instruments such as pollution standards ${ }^{19}$. The goal of this sub-indicator is to understand if these policy tools, which are fundamental for environmental policy stringency, harm competition by fostering different market conditions for similar firms. In particular, environmental policy can lead to discrimination of new entrants. For example, vintage differentiated regulation causes new entrants to face stricter regulation than established firms.

37. In the 2018 vintage of the DEEP, countries scored well on this sub-indicator (on average 1.52 out of 6). Israel, Ireland, Latvia and Switzerland all achieve a perfect score on this sub-indicator. For example, all countries but one declare that subsidies and tax breaks concerning GHG emissions and energy efficiency do not discriminate against new entrants. Concerning discrimination between sectors, $70 \%$ of countries report that there is no laxer treatment in environmental policies for specific industries such as large exporting companies or large emitters.

38. Between 2013 and 2018, the sub-indicator decreased by $24 \%$, indicating a decrease in the harm to competition caused by environmental policy (see Figure 12). For example,

${ }^{19}$ Huric-Larsen \& Münch, 2015. 
in 2018, only one country declares that subsidies and tax breaks concerning GHG emissions and energy efficiency can discriminate against new entrants. Countries scoring above OECD average in both 2013 and 2018 vintages drive this improvement while the score of most countries already scoring well in 2013 is stable. Denmark, Korea, France, and the Czech Republic underwent the biggest changes between 2013 and 2018 to reduce environmental policy harm to competition. An increase in this indicator is only observed for Estonia, Austria, and Slovakia.

Figure 12. Evolution of impediments to competition

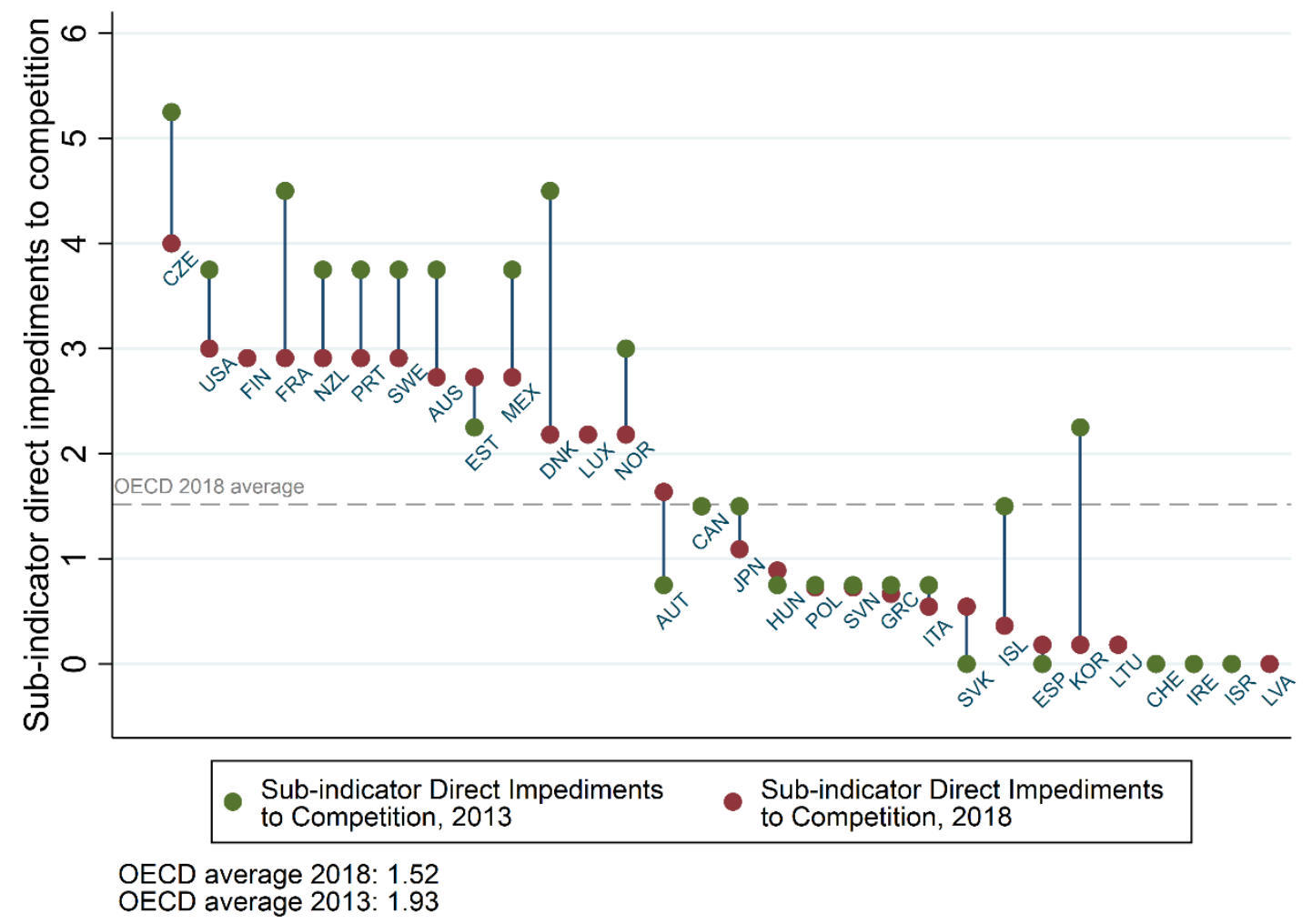

\subsection{Environmental Policy Evaluation is more systematic and transparent}

39. Decreasing by 28\% between 2013 and 2018, the sub-indicator Evaluation of New Policies contributes most to the drop in DEEP values, particularly among countries with the sharpest DEEP drop. The sub-indicators "evaluation of existing policy" and "evaluation of new policy" both aim to measure the quality of the environmental policy evaluation process. Rather than assessing specific policy issues such as permitting or vintage differentiated regulation, these two sections concentrate on the quality of the general environmental policymaking process. More specifically, these two sub-indicators focus on the existence and design of mandatory impact assessment procedures for environmental policies. They also provide insight on government policy transparency and accessibility. However, these two indicators do not measure the degree of actual enforcement of these policies.

40. In these two sections, countries score from 1.5 for Mexico to 10.2 for Italy, on a scale going from 0 to 12 (see Figure 13). Overall, countries are progressing towards making 
environmental policy evaluation procedures mandatory and transparent. Figure 13 strikingly illustrates that radical ex-ante and ex-post policy evaluation procedures overhauls in Spain, Israel, and Portugal spearhead this overall improvement in environmental policy evaluation. Box 1 further discusses the nature of these specific changes for these three countries.

Figure 13. Evolution of Environmental Policy Evaluation

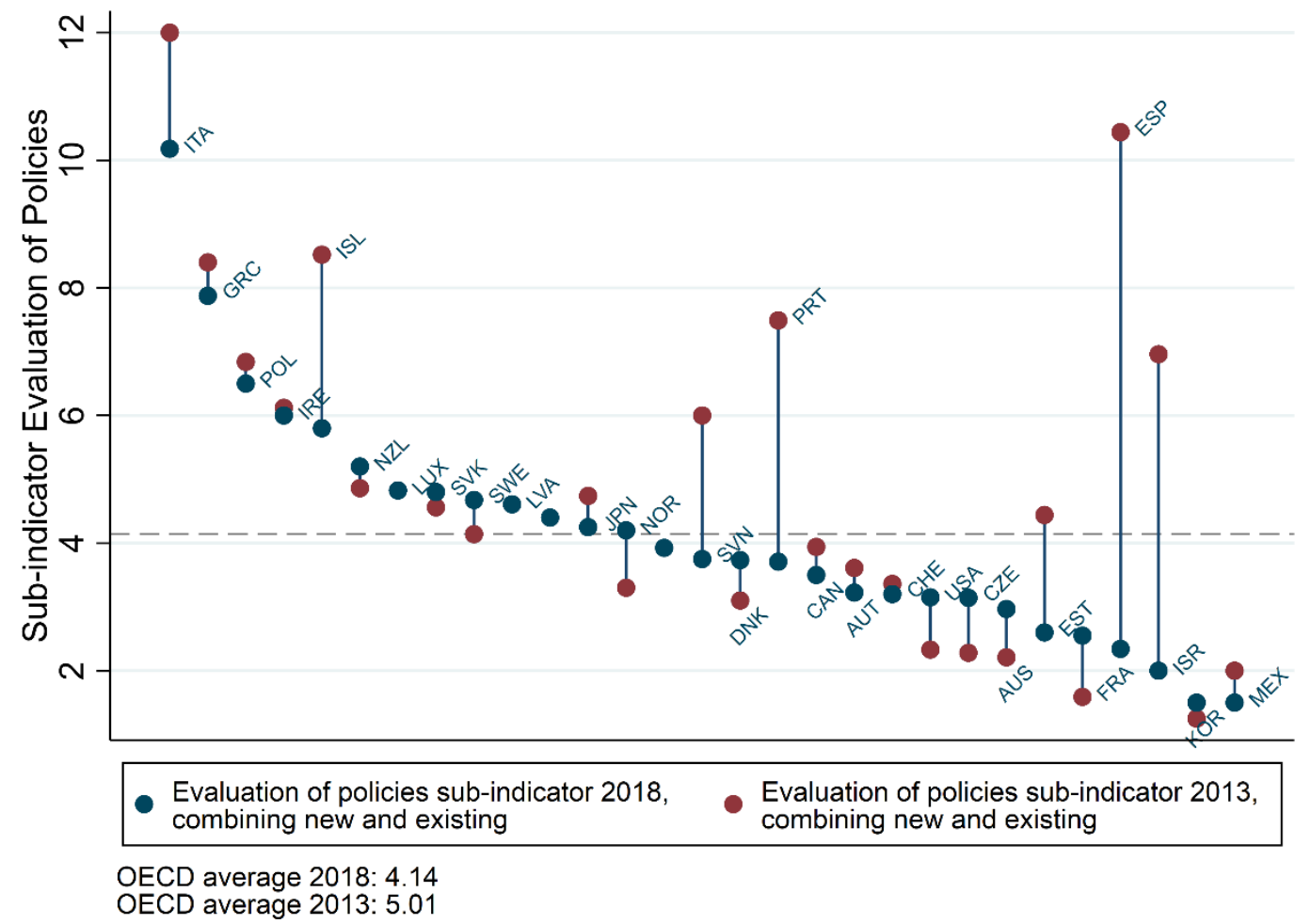

Note: The scale is from 0 to 12 because the category evaluation of policies combines two subindicators "Evaluation of New Policies" and "Evaluation of Existing Policies" which are scaled from 0 to 6 . 


\section{Box 1. National efforts to simplify and improve environmental policy procedures}

The drop in DEEP score of Spain, Israel, and Portugal is largely due to a national policy design overhaul

Spain, Israel, and Portugal have experienced some of the biggest changes in DEEP in our sample, with a drop of respectively 57\%, 56\%, and 34\% between 2013 and 2018 (see Figure $10)$. Following discussions with all three countries, it appears that this change stems in large part from efforts to simplify procedures and alleviate regulatory burdens on a national scale.

Spain and Israel implemented legislation aiming to follow OECD recommendations for policy assessment and transparency. This took the form of a 2017 Royal Decree for Spain and a 2014 Government Directive for Israel. In particular, both countries implemented systematic ex-ante and ex-post impact assessment procedures for all legislation. Thanks to the 2017 "Quanto Custa?" ("How much?") directive, ex-ante regulatory impact assessment is compulsory for any new legislation in Portugal. More precisely, this directive puts in place a mandatory macroeconomic cost and benefit analysis aiming to quantify the impact of any new legislation on the private sector.

This new setup for policy evaluation accounts for the sharp drop in the value of the subindicators evaluation of new and existing policies for all three countries, which dropped by $78 \%$ for Spain, $71 \%$ for Israel, and 50\% for Portugal (Figure 13).

In the case of Israel, the 2014 directive also explains the decrease in the value of the administrative burdens sub-indicator (-36\%). The directive seeks to cut administrative costs and simplify administrative procedures through digitalization. The drop in the value of this sub-indicator is also due to another directive targeting business licensing and permitting procedures. This directive aims at simplifying the process by enabling self-declaration mechanisms for low-impact facilities.

\subsection{The evolution of DEEP strongly correlates with that of environmental and regulatory indicators}

41. There is no significant correlation between DEEP and Environmental Performance Index (EPI) at given points in time (for 2013 and 2018). However, the variations of DEEP and EPI between 2013 and 2018 correlate significantly as shown in Figure 14, which presents their co-variation. The negative correlation between the EPI variation and the DEEP variation indicates that improving environmental quality correlates with decreasing DEEP values. The two countries most improving their EPI scores are Israel and Spain, which are also among the three countries with the sharpest drop in the value of the DEEP indicator. As explained, the drop in the DEEP score for these countries in mainly due to the sections related to policy evaluation. In these sections, the more criteria countries take into account when assessing environmental policy, the lower they score on the DEEP. Imposing additional criteria for environmental policy assessment is usually the expression of increased awareness to environmental outcomes. Increased concern about environmental quality could thus translate into more efficient policies. 
Figure 14. Correlation between the evolution of DEEP and the evolution of EPI (2012-2018)

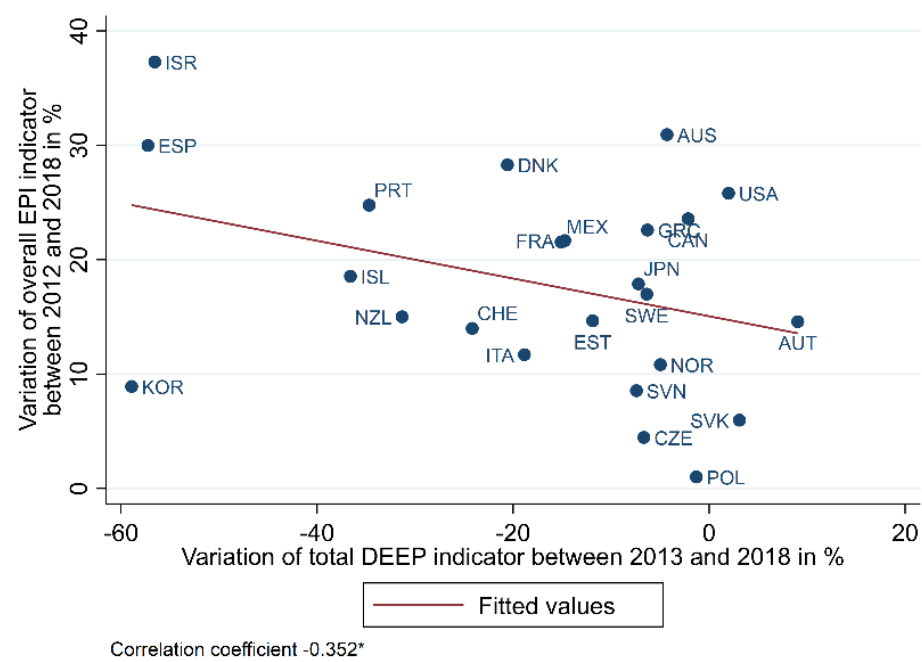

Note: For the EPI, the better the score the better the environmental outcome. The positive variation in EPI signals an improvement in environmental quality (EPI, 2018).

\subsection{Correlation between the evolution of DEEP and the evolution of PMR}

42. Similar to conclusions concerning the correlation of DEEP and EPI, there is a lack of correlation between DEEP and PMR on a cross-sectional perspective. This lack of correlation underscores the existence of dynamics specific to environmental policy. However, the evolutions of PMR and DEEP between 2013 and 2018 correlate significantly, as suggested by Figure 15, which presents the co-variation of DEEP and PMR. The correlation coefficient is high (0.42). This high correlation in the variation of PMR and DEEP indicates that changes in DEEP are associated with more general changes in regulatory frameworks, which are not specific to the environment. Discussions with Spain and Israel highlighted that changes in policy design on a national scale impacted the evolution of DEEP. Those general policy design changes should also affect PMR values. Some questions are common to both, although specific to environmental policy in the case of DEEP. 
Figure 15. Correlation between the evolution of DEEP and PMR (2013-2018)

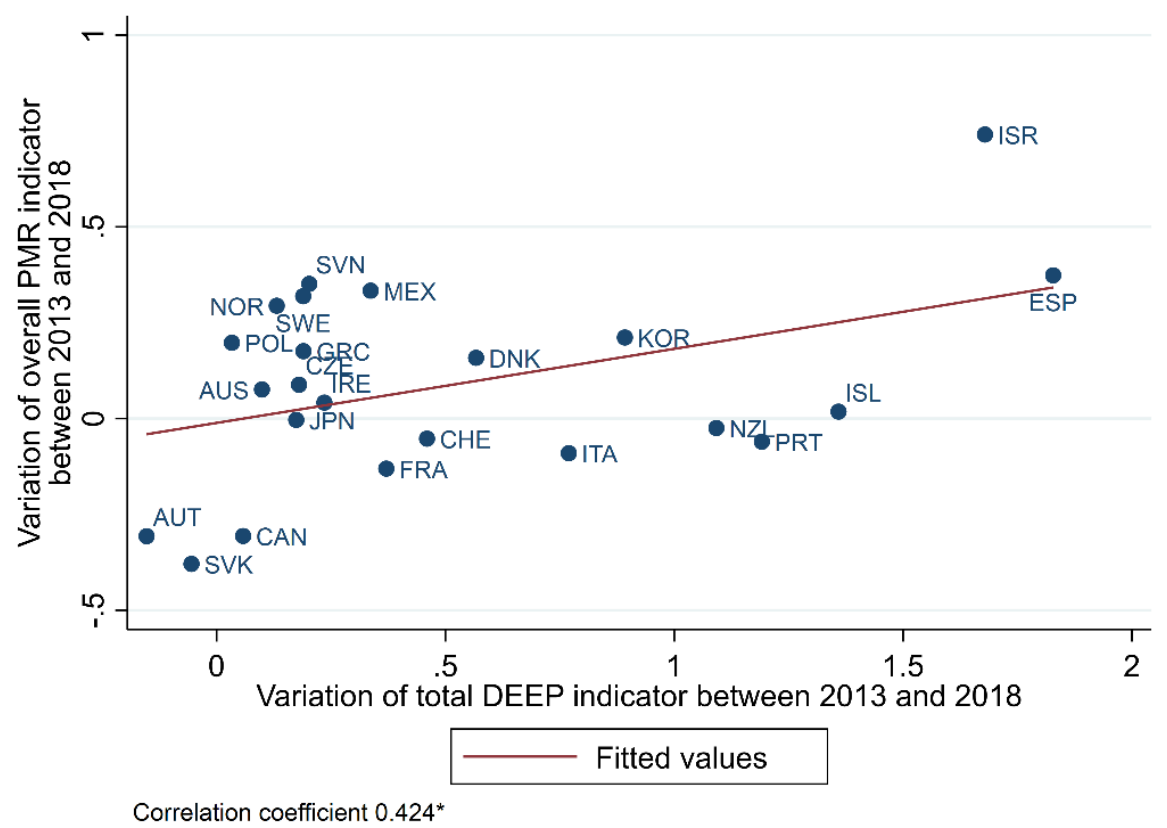

Note: The scale of the PMR indicator and DEEP is the same. 0 is the best score, 6 the worst score.

\section{Conclusion}

43. The average DEEP indicator for 2018 across the OECD is about $18 \%$ lower than the DEEP 2013, signaling a decrease in the burdens to competition and improved evaluation for environmental policies. This significant average change is partly driven by a sharp drop in the DEEP score of selected countries (Korea, Spain, Israel, Iceland, and Portugal), but over $80 \%$ of countries saw an improvement of DEEP between the two waves. On the one hand, the 2018 DEEP indicator comforts the insights from DEEP 2013. Across countries, there is little correlation between DEEP and the OECD's Environmental Policy Stringency indicator. This result shows that stringent environmental policies need not be associated with more burdens on the economy, and that some of these burdens apply specifically to the environmental domain. On the other hand, the evolution of the DEEP indicator over the last 5 years correlates significantly with the evolution of both PMR and EPI. Concerning PMR, this covariation highlights how efforts to alleviate regulatory burdens have affected all sectors, including the environment. Regarding EPI, this indicates that efforts to improve environmental outcomes are associated with efforts to simplify permitting procedures and to improve regulatory assessment. 


\section{References}

Global Footprint Network (2019), National Footprint and Biocapacity Accounts 2019, Global Footprint Network, Oakland, CA, USA. https://www.footprintnetwork.org/licenses/public-data-package-free/

Huric-Larsen, J.F., Münch, A. (2016) "Competition and Environmental Policy in the EU: Old Foes, New Friends?" in Jounral of Industry Competition and Trade, Vol 16(2) pp 137-153

Israel Government Resolution (2014), "Reducing the Regulatory Burden”, No. 2118 of October 22,http://www.pmo.gov.il/policyplanning/Regulation/Documents/Reducing $\% 20$ the $\% 20$ Regulatory $\% 2$ 0Burden.pdf (Isr).

Koźluk, T. (2014), "The Indicators of the Economic Burdens of Environmental Policy Design: Results from the OECD Questionnaire", OECD Economics Department Working Papers, No. 1178, OECD Publishing, Paris

OECD (2007), Guiding Principles of Effective Environmental Permitting Systems, OECD website, https://www.oecd.org/env/outreach/37311624.pdf

OECD (2012), Recommendation of the Council on Regulatory Policy and Governance. OECD website, https://www.oecd.org/gov/regulatory-policy/49990817.pdf

Gwartney J., Lawson R., Hall J., and Murphy R. (2018), Economic Freedom of the World: 2018 Annual Report. Fraser Institute, Toronto. https://www.fraserinstitute.org/studies/economic-freedom

Nicoletti, G., S. Scarpetta and O. Boylaud (2000), "Summary Indicators of Product Market Regulation with an Extension to Employment Protection Legislation", OECD Economics Department Working Papers, No. 226, OECD Publishing.

Schwab, K (2018), The Global Competitiveness Report 2018, Geneva: World Economic Forum.

Spanish Royal Decree 931/2017 (2017), “Memoria Del Análisis De Impacto Normativo Del Proyecto de Real Decreto por el que se regula la memoria del análisis de impacto normative, Ficha Del Resumen Ejecutivo", (Esp).

Vitale, C., et al. (2020), "The 2018 edition of the OECD PMR indicators and database: Methodological improvements and policy insights", OECD Economics Department Working Papers, No. 1604, OECD Publishing, Paris, https://doi.org/10.1787/2cfb622f-en.

Wendling, Z. A., Emerson, J. W., Esty, D. C., Levy, M. A., de Sherbinin, A., et al. (2018). 2018 Environmental Performance Index. New Haven, CT: Yale Center for Environmental Law \& Policy. https://epi.yale.edu/

World Bank (2018). Doing Business 2018: Reforming to Create Jobs. www.doingbusiness.org/content/dam/doingBusiness/media/Annual-Reports/English/DB2018-FullReport.pdf. 


\section{Annex A. Correlation Tables}

Table A.1. Correlation between DEEP and environmental indicators

\begin{tabular}{l|l|l|l}
\hline & Ecological footprint & EPI & EPS \\
\hline Total Indicator & 0.283 & & 0.0630 \\
\hline
\end{tabular}

Note: ${ }^{* \prime} p<0.10 * * p<0.05 * * * p<0.01$.

Table A.2. Correlation between DEEP and Fraser Institute Indicators on Regulation

\begin{tabular}{l|c|c|c}
\hline & Regulation & Regulatory Restrictions & $\begin{array}{l}\text { Administrative } \\
\text { Requirements }\end{array}$ \\
\hline Administrative Burdens & 0.00611 & -0.131 & 0.205 \\
\hline $\begin{array}{l}\text { Impediments to } \\
\text { Competition }\end{array}$ & 0.280 & -0.0993 & 0.208 \\
\hline $\begin{array}{l}\text { Evaluation of policies } \\
\text { (new) }\end{array}$ & -0.00937 & 0.0228 & -0.0750 \\
\hline $\begin{array}{l}\text { Evaluation of policies } \\
\text { (existing) }\end{array}$ & -0.109 & $0.356^{*}$ & -0.279 \\
\hline Total Indicator & 0.104 & -0.00703 & -0.127 \\
\hline
\end{tabular}

Note: ${ }^{* \prime} \mathrm{p}<0.10 * * \mathrm{p}<0.05 * * * \mathrm{p}<0.01$. The higher the Fraser indicators, the least harmful to economic freedom the different sub-indicators. The scale is thus the opposite that of DEEP.

Source: Fraser Institute World Economic Freedom Report 2018. This data table feeds on the sub-section Regulation. Regulatory Restrictions, Administrative Requirements, and Bureaucracy Costs are all part of the sub-indicator Regulation in the Fraser report (however, this indicator also includes other criteria).

Table A.3. Correlation between DEEP and Ease of Doing Business (World Bank)

\begin{tabular}{l|c}
\hline & Ease of Doing Business \\
\hline Administrative Burdens & -0.198 \\
\hline Direct Impediments to Competition & 0.243 \\
\hline Evaluation of policies (new) & $-0.356^{*}$ \\
\hline Evaluation of policies (existing) & -0.109 \\
\hline Total Indicator & -0.228 \\
\hline
\end{tabular}

Note: ${ }^{* \prime} \mathrm{p}<0.10 * * \mathrm{p}<0.05 * * * \mathrm{p}<0.01$. The higher the Ease of Doing Business the better the score. The scale is thus the opposite that of DEEP.

Source: World Bank Ease of Doing Business 2018. 
Table A.4. Correlation between DEEP and World Economic Forum Competitiveness Indicators

\begin{tabular}{l|c|c|c|c}
\hline & Transparency & $\begin{array}{c}\text { Domestic } \\
\text { Competition }\end{array}$ & $\begin{array}{c}\text { Distortive Effects on } \\
\text { competition }\end{array}$ & $\begin{array}{c}\text { Global } \\
\text { Competitiveness }\end{array}$ \\
\hline Administrative Burdens & 0.218 & $0.324^{*}$ & 0.283 & 0.214 \\
\hline $\begin{array}{l}\text { Direct Impediments to } \\
\text { Competition }\end{array}$ & 0.291 & 0.280 & $0.327^{*}$ & 0.273 \\
\hline $\begin{array}{l}\text { Evaluation of policies } \\
\text { (new) }\end{array}$ & 0.0860 & 0.111 & 0.0537 & -0.147 \\
\hline $\begin{array}{l}\text { Evaluation of policies } \\
\text { (existing) }\end{array}$ & -0.142 & -0.166 & -0.254 & $-0.328^{*}$ \\
\hline Total Indicator & 0.233 & 0.276 & 0.207 & 0.0253 \\
\hline
\end{tabular}

Note: ${ }^{* \prime} \mathrm{p}<0.10 * * \mathrm{p}<0.05 * * * \mathrm{p}<0.01$. The higher the WEF, the better the score. The scale is thus the opposite that of DEEP. We note a significant negative and expected correlation between the DEEP sub-indicator Evaluation of Existing Policies and WEF Global Competitiveness.

Source: These sub-indicators come from the Markets subdivision of the World Economic Forum Competitiveness Report 2018. The sub-indicators presented here are computed using the 2018 WEF Executive Opinion Suvey, which captures the views of business executives in 140 countries. These sub-indicators thus provide a business-oriented perspective, which completes the governmental approach the DEEP provides on environmental policy.

Table A.5. Correlation between DEEP and PMR

\begin{tabular}{l|r|r}
\hline & Administrative Burdens & Licences \\
\hline Administrative Burdens & 0.0639 & 0.165 \\
\hline Direct Impediments to Competition & -0.0650 & 0.108 \\
\hline Evaluation of policies (new) & 0.0211 & 0.0866 \\
\hline Evaluation of policies (existing) & 0.0201 & -0.146 \\
\hline Total Indicator & 0.0437 & 0.127 \\
\hline
\end{tabular}

Note: ${ }^{* 1} \mathrm{p}<0.10 * * \mathrm{p}<0.05 * * * \mathrm{p}<0.01$. This table examines the correlation between DEEP and specific sections of the PMR 2018: Administrative Burdens and Licences.

Source: The PMR (Product Market Regulation) pertains to all sectors of the economy. 


\section{Annex B. Correlation between permitting costs and environmental policy stringency}

Figure B.1. Correlation between Environmental Permitting Cost and Environmental Policy Stringency

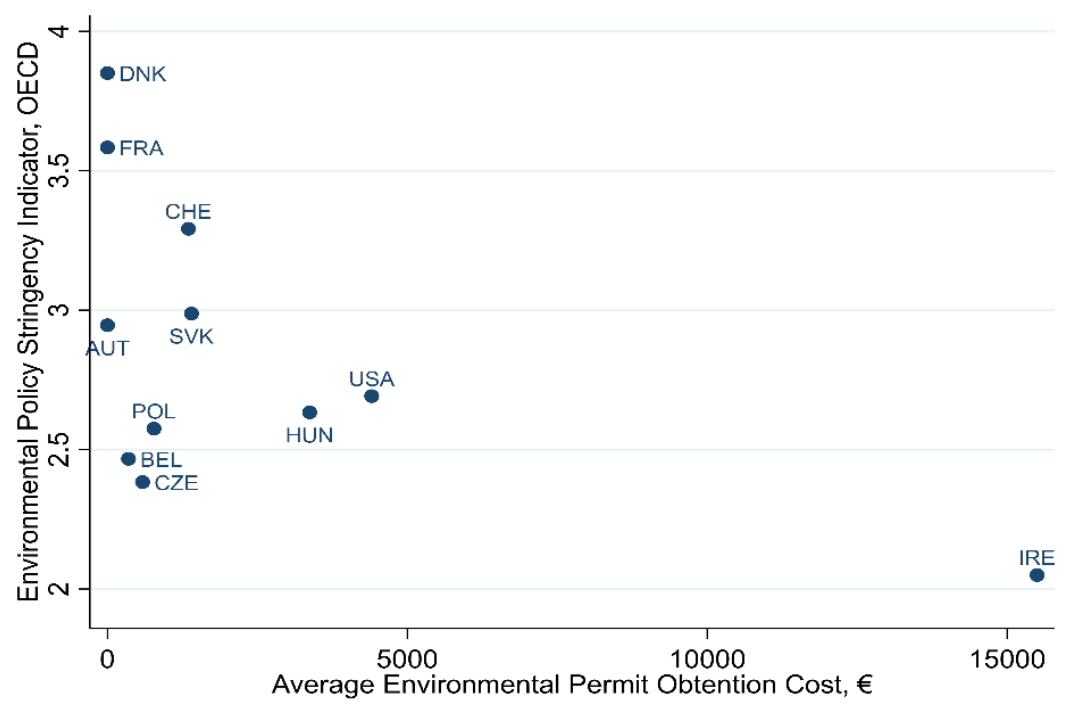

Note: EPS is scaled from 0 to 6 with 6 being the most stringent policy. Conversation rates July 2019. 
Annex C. Summary statistics for Permitting Times and Costs

Table A C.1. Summary Statistics for Permitting Times and Costs

\begin{tabular}{lrrrrr}
\hline Variable & Obs & Mean & Std.Dev. & Min & Max \\
\hline $\begin{array}{l}\text { Legal Permitting Time for Low- } \\
\text { Environmental Impact Firms (days) }\end{array}$ & 20 & 104.3 & 73.05 & 20 & 270 \\
$\begin{array}{l}\text { Legal Permitting Time for High- } \\
\text { Environmental Impact Firms (days) }\end{array}$ & 23 & 189 & 147.8 & 22 & 730 \\
$\begin{array}{l}\text { Average Permitting Time for Low- } \\
\text { Environmental Impact Firms (days) }\end{array}$ & 14 & 88.14 & 61.4 & 35 & 225 \\
$\begin{array}{l}\text { Average Permitting Time for Low- } \\
\text { Environmental Impact Firms (days) }\end{array}$ & 18 & 175.56 & 132.79 & 35 & 450 \\
$\begin{array}{l}\text { Average Permitting Cost for Low- } \\
\text { Environmental Impact firms ( } € \text { ) }\end{array}$ & 17 & 1374.29 & 2019.09 & 0 & 6402 \\
$\begin{array}{l}\text { Average Permitting Cost for High- } \\
\text { Environmental Impact firms ( } € \text { ) } \\
\text { Average Legal Permitting Time for all } \\
\text { types of firms (days) }\end{array}$ & 18 & 3767.94 & 6254.61 & 0 & 25000 \\
$\begin{array}{l}\text { Average Actual Permitting Time for } \\
\text { all types of firms (days) }\end{array}$ & 14 & 134.97 & 74.18 & 42.5 & 316.5 \\
\hline
\end{tabular}

Note: Permitting Time refers to the duration of the procedures and is reported in days.

Source: OECD 2018 BEEP questionnaires, questions QA3110-QA3114. 


\section{Annex D. Breakdown of DEEP per country}

Table A D.1. 2018 DEEP values for OECD countries

\begin{tabular}{|c|c|c|c|c|c|}
\hline country & Total Indicator & $\begin{array}{r}\text { Administrative } \\
\text { Burdens }\end{array}$ & $\begin{array}{r}\text { Direct } \\
\text { Impediments to } \\
\text { Competition }\end{array}$ & $\begin{array}{c}\text { Evaluation of } \\
\text { Existing Policies }\end{array}$ & $\begin{array}{r}\text { Evaluation of New } \\
\text { Policies }\end{array}$ \\
\hline AUS & 2.203 & 3.120 & 2.727 & 2.042 & 0.925 \\
\hline AUT & 1.846 & 2.521 & 1.636 & 2 & 1.225 \\
\hline BEL & & 2.160 & $\cdot$ & . & \\
\hline CAN & 2.656 & 5.625 & 1.5 & 1.300 & 2.200 \\
\hline $\mathrm{CHE}$ & 1.442 & 2.568 & 0 & 2.400 & 0.800 \\
\hline CZE & 2.526 & 2.961 & 4 & 1.542 & 1.600 \\
\hline DNK & 2.187 & 2.834 & 2.182 & 2.583 & 1.150 \\
\hline ESP & 1.364 & 2.933 & 0.182 & 2.042 & 0.300 \\
\hline EST & 1.987 & 2.620 & 2.727 & 2 & 0.600 \\
\hline FIN & 2.605 & 3.109 & 2.909 & 3 & 1.400 \\
\hline FRA & 2.145 & 3.120 & 2.909 & 2.100 & 0.450 \\
\hline GRC & 2.827 & 2.765 & 0.667 & 4.5 & 3.375 \\
\hline HUN & & 2.364 & 0.889 & . & \\
\hline IRE & 2.064 & 2.257 & 0 & 3.5 & 2.5 \\
\hline ISL & 2.354 & 3.254 & 0.364 & 3.5 & 2.300 \\
\hline ISR & 1.289 & 3.157 & 0 & 2 & 0 \\
\hline ITA & 3.313 & 2.525 & 0.545 & 5.5 & 4.680 \\
\hline JPN & 2.239 & 3.615 & 1.091 & 2.750 & 1.5 \\
\hline KOR & 0.622 & 0.805 & 0.182 & 1.5 & 0 \\
\hline LTU & 1.552 & 2.101 & 0.182 & 3 & 0.925 \\
\hline LUX & 2.907 & 4.620 & 2.182 & 1.200 & 3.625 \\
\hline LVA & 1.603 & 1.805 & 0 & 3.208 & 1.400 \\
\hline MEX & 1.892 & 3.340 & 2.727 & 1.5 & 0 \\
\hline NOR & 2.506 & 3.643 & 2.182 & 2.700 & 1.5 \\
\hline NZL & 2.393 & 1.462 & 2.909 & 3.5 & 1.700 \\
\hline POL & 2.516 & 2.836 & 0.727 & 4 & 2.5 \\
\hline PRT & 2.243 & 2.354 & 2.909 & 2.083 & 1.625 \\
\hline SVK & 1.833 & 1.985 & 0.545 & 4 & 0.800 \\
\hline SVN & 2.526 & 5.625 & 0.727 & 2.5 & 1.250 \\
\hline SWE & 2.783 & 3.549 & 2.909 & 3.250 & 1.425 \\
\hline TUR & & 3 & . & . & \\
\hline USA & 2.569 & 4.125 & 3 & 2 & 1.150 \\
\hline
\end{tabular}

Note: The total indicator as well as sub-indicators are scaled from 0 (best) to 6 (worst). 


\section{Annex E. Scoring and aggregation procedures}

\section{Table E.1. Sub-indicator on administrative burdens}

Details for the computation of the sub-indicator.

\begin{tabular}{|c|c|c|}
\hline Questions & Answers & Scoring \\
\hline $\begin{array}{l}\text { (A) If different environmental permits licenses for common } \\
\text { manufacturing activities exist, what are the most common } \\
\text { features? [QA3.1.2] } \\
\text { Permits vary by type of activity (e.g. industry) } \\
\text { Permits vary by size of plant [QA3.1.2b] } \\
\text { Permits vary by type of environmental impact [QA3.1.2c] } \\
\text { Permits vary by location [QA3.1.2d] } \\
\text { Permits need to be renewed periodically [QA3.1.2e] }\end{array}$ & Score of $1 / 5$ for each no & \\
\hline \multirow{3}{*}{$\begin{array}{l}\text { (B) How can an entrepreneur about to set up a company find out } \\
\text { whether the company will be subject to specific environmental } \\
\text { licensing? [QA3.1.3] }\end{array}$} & $\begin{array}{l}\text { There is a website containing detailed information on } \\
\text { requirements about environmental permitting }\end{array}$ & 0 \\
\hline & $\begin{array}{l}\text { The entrepreneur will be informed during the company } \\
\text { registration process about need for environmental permits } \\
\text { (general or activity specific) }\end{array}$ & 0.5 \\
\hline & $\begin{array}{l}\text { The entrepreneur is responsible for finding this } \\
\text { information on her/his own }\end{array}$ & 1 \\
\hline \multirow{5}{*}{$\begin{array}{l}\text { (C) Is there a list of clear criteria for defining a "high } \\
\text { environmental risk" or high polluting industrial facility? [QA3.1.4] }\end{array}$} & Yes, they are published on line in one document/website & 0 \\
\hline & Yes, they are available in a single document but not online & 0.2 \\
\hline & $\begin{array}{l}\text { Yes, but they are defined in a number of legal documents, } \\
\text { depending e.g. on the type of environmental risks }\end{array}$ & 0.5 \\
\hline & $\begin{array}{l}\text { This is assessed on a case by case, by the relevant } \\
\text { government authority (please list which) }\end{array}$ & 0.7 \\
\hline & No such criteria exist & 1 \\
\hline \multirow{3}{*}{$\begin{array}{l}\text { (D) Is there a single contact point where the entrepreneur can } \\
\text { obtain all necessary environment-related permits/licenses? } \\
\text { [QA3.1.5] }\end{array}$} & $\begin{array}{l}\text { There is such a single contact point and it is the same } \\
\text { contact point as for other necessary registration/start-up } \\
\text { procedures (full one stop shop) }\end{array}$ & 0 \\
\hline & $\begin{array}{l}\text { There is such a single contact point, but it is not the same } \\
\text { contact point as for other necessary registration/start-up } \\
\text { procedures (environmental one stop shop) }\end{array}$ & 0.5 \\
\hline & $\begin{array}{l}\text { There is no single contact point for environmental } \\
\text { procedures and firms must contact } \\
\text { more than one entity }\end{array}$ & 1 \\
\hline \multirow{3}{*}{$\begin{array}{l}\text { (E) Is there a single contact point where an entrepreneur about to } \\
\text { open a business (or plant) can submit all necessary } \\
\text { environment-related notifications? [QA3.1.6] }\end{array}$} & $\begin{array}{l}\text { There is such a single contact point and it is the same } \\
\text { contact point as for other necessary registration/start-up } \\
\text { procedures (full one stop shop) }\end{array}$ & 0 \\
\hline & $\begin{array}{l}\text { There is such a single contact point, but it is not the same } \\
\text { contact point as for other necessary registration/start-up } \\
\text { procedures (environmental one stop shop) }\end{array}$ & 0.5 \\
\hline & $\begin{array}{l}\text { There is no single contact point for environmental } \\
\text { procedures and firms must contact } \\
\text { more than one entity }\end{array}$ & 1 \\
\hline
\end{tabular}



environmental licenses/permits be done with a single application form? [QA3.1.7]

\begin{tabular}{|c|c|}
\hline Yes, online or manually & 0 \\
\hline Yes, but only manually & 0.5 \\
\hline $\begin{array}{l}\text { It can only be done with multiple forms (e.g. regarding } \\
\text { different environmental permits or different institutions, } \\
\text { such as national and local), but all can be arranged online }\end{array}$ & 0.5 \\
\hline It can be done with multiple forms, but not online & 1 \\
\hline Yes, always & 0 \\
\hline Yes, for most standard business activity & 0 \\
\hline No & 1 \\
\hline Yes & 0 \\
\hline No & 1 \\
\hline $\begin{array}{l}\text { Number of days (or average if several numbers are } \\
\text { mentioned) divided by the } 90 \text { th percentile of our sample }\end{array}$ & \\
\hline $\begin{array}{l}\text { Number of days (or average if several numbers are } \\
\text { mentioned) divided by the } 90 \text { th percentile of our sample }\end{array}$ & \\
\hline Yes & 0 \\
\hline No & 1 \\
\hline Yes & 0 \\
\hline No & 1 \\
\hline $\begin{array}{l}\text { Number of days (or average if several numbers are } \\
\text { mentioned) divided by the } 90 \text { th percentile of our sample }\end{array}$ & \\
\hline $\begin{array}{l}\text { Number of days (or average if several numbers are } \\
\text { mentioned) divided by the } 90 \text { th percentile of our sample }\end{array}$ & \\
\hline
\end{tabular}

(G) Is there an integrated environmental permit/licence for all key environmental effects? [QA3.1.8]

(H) Does the « silence is consent rule apply to environmental permits/licences? [QA3.1.9]

(I) What is the legal time limit on responsible bodies to issue environment related permits or licenses - For Large/High Impact Facilities? [QA3.1.10a]

(J) What is the legal time limit on responsible bodies to issue environment related permits or licenses - For SME"s/Low Impact Facilities? [QA3.1.10b]

(K) Is there a simplified permitting/notification procedure for SME's or activities with low environmental risks? [QA3.1.11]

(L) Does the simplified procedure for SME's/lowenvironmental risks involve only one single contact point or single application form? [QA3.1.12]

(M) How long, on average, does the approval process take (number of days)? - For a low risk/low impact facilitiy? [QA3.1.13a]

(N) How long, on average, does the approval process take (number of days)? - For a high risk/high impact facilitiy? [QA3.1.13b]

\section{Aggregation formula}

Indicator of administrative burdens $=[\mathrm{A}+\mathrm{B}+\mathrm{C}+(0.5 \mathrm{D}+0.5 \mathrm{E})+\mathrm{F}+\mathrm{G}+\mathrm{H}+\mathrm{I}+\mathrm{J}+\mathrm{K}+(1-\mathrm{K}) *(0.5 \mathrm{~L})+\mathrm{M}+\mathrm{N}] / 12$ (if a country has provided an answer to every question, otherwise the denominator is adjusted to reflect this) 
Table E.2. Sub-indicator on Direct Impediments to Competition

Details for the computation of the sub-indicator.

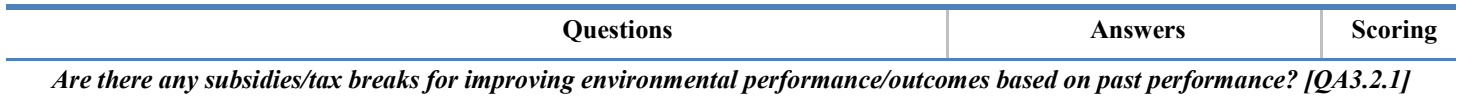

(A) If subsidies/tax breaks for improving performance,based on historical outcomes exist in the area of climate change (GHG emissions, energy efficiency etc.) can they be viewed as discriminating against new entrants?[QA3.2.1a]

(B) If subsidies/tax breaks for improving performance,based on historical outcomes exist in the area of air pollution can they be viewed as discriminating against new entrants? [QA3.2.1b]

(C) If subsidies/tax breaks for improving performance, based on historical outcomes exist in the area of water management (use efficiency and pollution) can they be viewed as discriminating against new entrants?[QA3.2.1c]

(D) If dedicated subsidies/tax breaks for environmental innovation (e.g. "green" R\&D spending) exist can they be viewed as discriminating against new entrants - e.g. being based on a history of R\&D spending which new entrants may not have, or take the form of tax breaks

Vintage-Differentiated Regulation - for a new firm planning to enter one of the industries below, can it face any type of stricter environmental standards/regulation (e.g. Regarding air pollutant or water pollutant emissions, waste, water abstraction, energy

efficiency) than an existing firm of similar size and activity? [QA3.2.2]

(E) Mining and quarrying (B in ISIC rev. 4.0)[QA3.2.2a]

(F) Manufacture of chemicals and chemical products(C20 in ISIC rev. 4.0) [QA3.2.2b]

(G) Manufacture of rubber and plastic products (C22 in ISIC rev. 4.0) [QA3.2.2c]

(H) Manufacture of basic metals (C24 in ISIC rev. 4.0) [QA3.2.2d]

(I) Electricity, gas, steam and air conditioning supply (D in ISIC rev. 4.0) [QA3.2.2e]

(J) Are there special provisions for laxer treatment in environmental policies (lower tax rates, free allocation of permits, preferential access to subsidies) for small firms (e.g. SMEs) regardless of their actual environmental impact? [QA3.2.4] If such provisions exist are they applied in the area of climate change (GHG emissions, energy efficiency etc.) [QA3.2.4a]

If such provisions exist are they applied in the area of air pollution [QA3.2.4b]

If such provisions exist are they applied in the area of air pollution [QA3.2.4b]

If such provisions exist are they applied in the area of water management [QA3.2.4c]

(H) Are there any environmental domains in which companies need to purchase environmental offsets to enter the market or expand capacity (or increase environmental impact)? [QA3.2.7]

In the area of climate change (GHG emissions, energy efficiency etc.) [QA3.2.7a]

In the area of air pollution [QA3.2.7b]

In the area of water management [QA3.2.7c]

\begin{tabular}{|r|r}
\hline Yes & 1 \\
\hline No & 0 \\
\hline Yes & 1 \\
\hline No & 0 \\
\hline Yes & 1 \\
\hline No & 0 \\
\hline Yes & 1 \\
\hline No & 0 \\
\hline
\end{tabular}




\section{Table E.3. Sub-indicator on the evaluation of new policies}

Details for the computation of the sub-indicator.

\begin{tabular}{|c|c|c|}
\hline Questions & Scoring of answers & \\
\hline \multirow{4}{*}{$\begin{array}{l}\text { (A) Is there a legal obligation to evaluate the impact of newlyproposed environmental policies } \\
\text { on economic activity?[QA3.3.1 }\end{array}$} & Yes & 0 \\
\hline & $\begin{array}{l}\text { Yes, for "major" changes in } \\
\text { policy instruments }\end{array}$ & 0.3 \\
\hline & $\begin{array}{l}\text { It is a practice, but not legally } \\
\text { binding }\end{array}$ & 0.5 \\
\hline & No & 1 \\
\hline $\begin{array}{l}\text { (B) What criteria are taken into account when evaluating the economic effects of an } \\
\text { environmental policy proposal? [QA3.3.2] } \\
\text { Competition [QA3.3.2a] } \\
\text { Entry/exit barriers }[Q A 3.3 .2 b] \\
\text { Trade competitiveness [QA3.3.2c] } \\
\text { Specific effects on } S M E^{\prime} \text { ' }[Q A 3.3 .2 d] \\
\text { Employment [QA3.3.2e] } \\
\text { Innovation [QA3.3.2f] } \\
\text { Administrative burden imposed by theregulation/policy [QA3.3.2g] } \\
\text { Statisticalregulation/policy [QA3.3.2h] }\end{array}$ & Score of $1 / 8$ for each no & \\
\hline \multirow[t]{3}{*}{ (C ) Are there clear rules or guidelines on how such analysis should be conducted? [QA3.3.3] } & Yes, national & 0 \\
\hline & Yes, state level & 0 \\
\hline & No & 1 \\
\hline \multirow[t]{2}{*}{ (D) Are the existing rules/guidelines for such an analysis legally binding? [QA3.3.4] } & Yes & 0 \\
\hline & No & 1 \\
\hline \multirow{2}{*}{$\begin{array}{l}\text { (E) Are the results of such evaluations of policy options and effects publicly available? } \\
\text { [QA3.3.5] }\end{array}$} & Yes & 0 \\
\hline & No & 1 \\
\hline $\begin{array}{l}\text { (F) Are any of the below explicitly required when evaluating new policy proposals? [QA3.3.6] } \\
\text { Interactions and overlaps with existing policies [QA3.3.6a] } \\
\text { Benchmarking against alternative policy instruments to achieve the same environmental goal } \\
\text { [QA3.3.6b] } \\
\text { Comparison of marginal abatement costs across sectors/activities [QA3.3.6c] } \\
\text { Evaluation of costs and benefits with respect to using a pricing instrument (e.g. emission tax)? } \\
\text { [QA3.3.6d] } \\
\text { Evaluation of costs and benefits of pursuing the same goal at a particular level of } \\
\text { administration (e.g. national, state, local) [QA3.3.6e] }\end{array}$ & Score of $1 / 5$ for each no & \\
\hline \multirow{4}{*}{$\begin{array}{l}\text { (G) Are stakeholders consulted preceding the selection of a given environmental policy tool? } \\
\text { [QA3.3.8] }\end{array}$} & Yes & 0 \\
\hline & $\begin{array}{l}\text { This is a practice, but not } \\
\text { legally binding }\end{array}$ & 0.3 \\
\hline & This is sometimes done & 0.7 \\
\hline & No & 1 \\
\hline \multirow{2}{*}{$\begin{array}{l}\text { (H) Is there a website where all new environment-related regulation is announced? } \\
\text { [QA3.3.9] }\end{array}$} & There is one website & 0 \\
\hline & No & 1 \\
\hline
\end{tabular}

\section{Aggregation Formula}

Indicator of evaluation of new policies $=[\mathrm{A}+\mathrm{B}+\mathrm{C}+(1-\mathrm{C}) *(0.5 \mathrm{D}+0.5 \mathrm{~F})+\mathrm{E}+\mathrm{G}+\mathrm{H}) / 6$

(if a country has provided an answer to every question, otherwise the denominator is adjusted to reflect this) 


\section{Table E.4. Sub-indicator on the evaluation of existing policy}

Details for the computation of the sub-indicator

\begin{tabular}{|c|c|c|}
\hline Questions & & $\begin{array}{l}\text { Scoring of } \\
\text { answers }\end{array}$ \\
\hline \multirow[t]{3}{*}{$\begin{array}{l}\text { (A) Is there a programme to evaluate the costs and benefits of } \\
\text { introduced environmental policies ex post? [QA3.4.1] }\end{array}$} & $\begin{array}{l}\text { Yes, evaluating both the achievement of } \\
\text { environmental goals and the economic costs } \\
\text { of environmental policy/regulation }\end{array}$ & 0 \\
\hline & $\begin{array}{l}\text { Yes, but focusing on evaluation with respect } \\
\text { to the achievement of environmental goals }\end{array}$ & 0.5 \\
\hline & No & 1 \\
\hline \multirow[t]{3}{*}{$\begin{array}{l}\text { (B) Is there a regular review of existing environmental policies to } \\
\text { determine whether they are achieving their stated objective? } \\
\text { [QA3.4.2] }\end{array}$} & $\begin{array}{l}\text { Regular programme (this can include a } \\
\text { mandatory one-off evaluation X years after a } \\
\text { policy was introduced) }\end{array}$ & 1 \\
\hline & $\begin{array}{l}\text { No regular programme, but ad-hoc reviews } \\
\text { have taken place }\end{array}$ & 0.5 \\
\hline & No & 0 \\
\hline \multicolumn{3}{|l|}{$\begin{array}{l}\text { (C) Does such an evaluation explicitly look at the } \\
\text { followingaspects? [QA3.4.3] }\end{array}$} \\
\hline \multicolumn{3}{|l|}{$\begin{array}{l}\text { Economic costs at which the goals are being pursued, relative } \\
\text { toalternative tools (benchmarking) [QA3.4.3a] } \\
\text { Equalisation of abatement costs across sectors, activities or } \\
\text { companies [QA3.4.3b] } \\
\text { The overall administrative burden imposed on } \\
\text { companies[QA3.4.3c] } \\
\text { Ways to streamline the administrative procedures [QA3.4.3d] } \\
\text { Overlaps in different areas of responsibilities among } \\
\text { administration levels/bodies [QA3.4.3e] } \\
\text { Possibilities of reducing the amount of requested statistical } \\
\text { information (e.g. not asking the same information twice) } \\
\text { [QA3.4.3f] }\end{array}$} \\
\hline \multirow[t]{2}{*}{ (D) Are such reviews ports publicly available? [QA3.4.4] } & Yes & 0 \\
\hline & No & 1 \\
\hline \multirow{2}{*}{$\begin{array}{l}\text { (E) Are companies obliged to collect information that would allow } \\
\text { such an evaluation of policies? [QA3.4.5] }\end{array}$} & Yes & 0 \\
\hline & No & 1 \\
\hline \multirow{4}{*}{$\begin{array}{l}\text { (F) Is there a database of all (national, state, local) environmental } \\
\text { policy instruments addressing specific environmental issues? } \\
\text { [QA3.4.6] }\end{array}$} & Yes, all & 0 \\
\hline & Only state and/or national level policies & 0.5 \\
\hline & Only "major" policy instruments in place & 0.5 \\
\hline & No & 1 \\
\hline \multirow{4}{*}{$\begin{array}{l}\text { (G) Can businesses or stakeholders propose simplification and } \\
\text { improvements or flag particularly burdensome regulations? } \\
\text { [QA3.4.7] }\end{array}$} & $\begin{array}{l}\text { Yes, they have the opportunity to do so on a } \\
\text { continuous basis }\end{array}$ & 0 \\
\hline & Yes, they are regularly encouraged to do so & \\
\hline & $\begin{array}{l}\text { Ad-hoc or occasionally (e.g. during } \\
\text { government reform) }\end{array}$ & \\
\hline & No & 1 \\
\hline
\end{tabular}

\section{Aggregation Formula}

Indicator of evaluation of existing policies $=[\mathrm{A}+\mathrm{B}+(1-\mathrm{A})(1-\mathrm{B})(0.5 \mathrm{C})+\mathrm{D}+\mathrm{E}+\mathrm{F}+\mathrm{G}) / 6$

(if a country has provided an answer to every question, otherwise the denominator is adjusted to reflect this) 


\section{Annex F. Country Response Rates to EEP questionnaires}

\section{Table A F.1. Country Response Rates}

\begin{tabular}{|c|c|}
\hline Country & Response Rate (\%) \\
\hline AUS & 94.59 \\
\hline AUT & 100 \\
\hline BEL & 48.65 \\
\hline CAN & 78.38 \\
\hline CHE & 97.30 \\
\hline CHL & 0 \\
\hline $\mathrm{CZE}$ & 100 \\
\hline DEU & 0 \\
\hline DNK & 100 \\
\hline ESP & 94.59 \\
\hline EST & 100 \\
\hline FIN & 94.59 \\
\hline FRA & 91.89 \\
\hline GBR & 0 \\
\hline GRC & 89.19 \\
\hline HUN & 75.68 \\
\hline IRE & 97.30 \\
\hline ISL & 100 \\
\hline ISR & 94.59 \\
\hline ITA & 91.89 \\
\hline JPN & 91.89 \\
\hline KOR & 89.19 \\
\hline LTU & 97.30 \\
\hline LUX & 91.89 \\
\hline LVA & 86.49 \\
\hline MEX & 97.30 \\
\hline NLD & 0 \\
\hline NOR & 83.78 \\
\hline NZL & 94.59 \\
\hline POL & 91.89 \\
\hline PRT & 97.30 \\
\hline SVK & 100 \\
\hline SVN & 89.19 \\
\hline SWE & 94.59 \\
\hline TUR & 27.03 \\
\hline USA & 86.49 \\
\hline ZAF & 0 \\
\hline
\end{tabular}

Note: This presents response rates only for questions included in the final indicator, not in the questionnaire as a whole. This table presents response rates for all countries to whom the questionnaire was sent. 